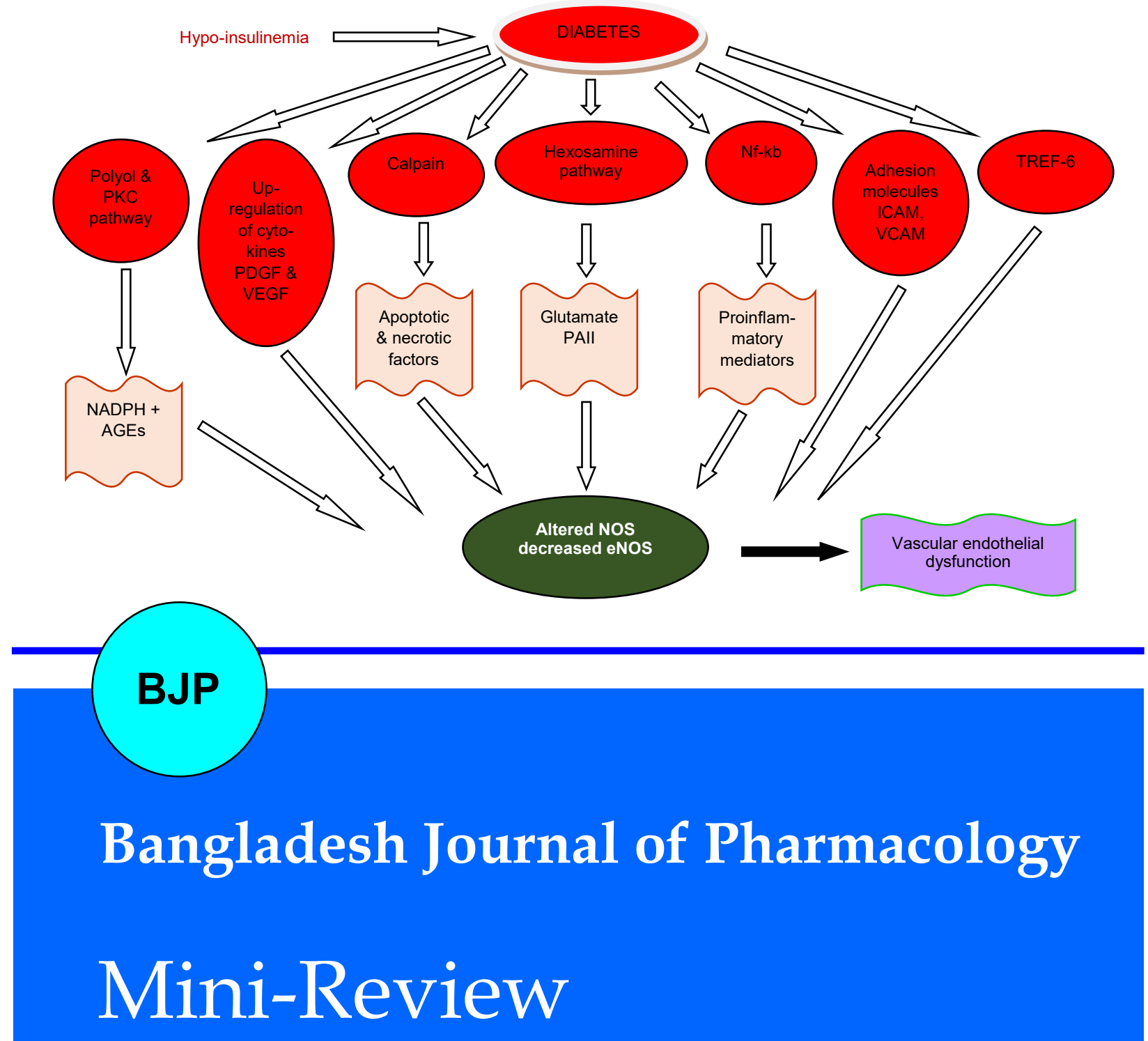

\title{
Experimental models for vascular endothelial dysfunction
}




\title{
Experimental models for vascular endothelial dysfunction
}

\author{
Anchal Garg1, Vardan Gupta', Ritu Tomar' and Mandeep Kumar Arora² \\ ${ }^{1}$ Department of Pharmacology, KIET School of Pharmacy, KIET group of Institutions, Ghaziabad 201001, India; \\ ${ }^{2}$ School of Pharmaceutical and Population Health Informatics, DIT University, Dehradun 248009, Uttarakhand, India.
}

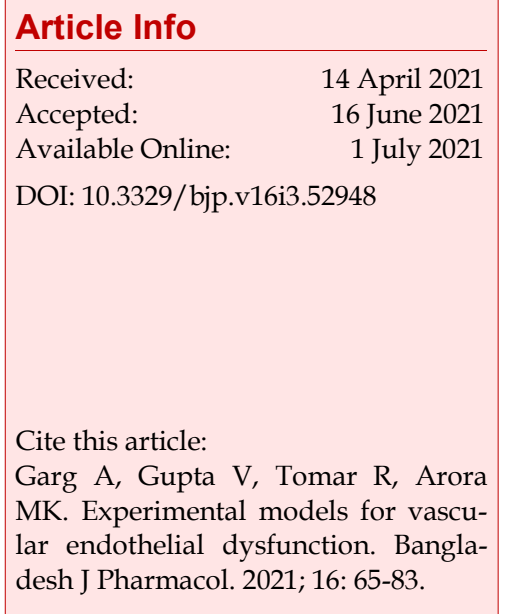

\begin{abstract}
Vascular endothelial dysfunction is characterized by apoptosis of endothelial cells, an imbalance between vasoconstrictory and vasodilatory substances, the imbalance between ROS and antioxidants, vascular remodeling, loss of vascular integrity which leads to an increased risk of cardiovascular complications. To date, no therapeutic intervention is available as a promising agent. This may be due to a poor understanding of the underlying mechanism involved in vascular endothelial dysfunction in the pathogenesis. Animal models sharing identical features as that of humans are paramount to understand fundamental physiology, mechanism and to explore new targets for developing therapeutic agents. Thus, it becomes mandatory to re-explore the available animal models for a better understanding of molecular pathways involving vascular endothelial dysfunction. The purpose of this paper is to review different models for vascular endothelial dysfunction to the outlook for developing new drugs to treat vascular endothelial dysfunction.
\end{abstract}

\section{Introduction}

The vascular endothelium is the innermost lining of the blood vessel. It is a metabolically active layer that tends to release various substances that control vascular relaxation and contraction as well as enzymes that control blood clotting, immune function, and platelet adhesion (Sandoo et al., 2010). It plays a crucial role in maintaining vascular tone, integrity, and free flow of the blood under normal physiology. Destruction or injury in the endothelial layer of arteries leads to create an imbalance between vasoconstriction and vasodilatation factors which complicate vascular endothelial dysfunction and lead to cause various other severe cardiovascular disorders. An increase in free radicle production (ROS/RNS), NADPH oxidase, xanthin-oxidase or decrease in glutathione, no generation is the underlying pathways involved in the pathogenesis of vascular endothelial dysfunction. Regulation of inflammatory mediators such as intracellular adhesion molecule-1, von Willi brand factor, Nf-kb and growth factors like endothelin-1, VEGF, PDGF, OLGF, and ILs mutually affect vascular endothelium (Balakumar et al., 2008a) Atherosclerosis, hypertension, hyperglycemia, and smoking are considered to be the self-governing risk factors and foremost determinants in the progression of vascular endothelial dysfunction (Hadi et al., 2005). To identify the potential pharmacological targets for vascular endothelial dysfunction in different experimental models are designed and employed to induce the vascular endothelial dysfunction. Therefore, this paper aims to review various experimental animal models developed to produce vascular endothelial dysfunction.

\section{Animal models}

Human vascular endothelial dysfunction shares many features which are common with animals. In contrast to direct study on human, animal models are easily manageable, as experimental conditions can be controlled. Vascular and cardiac tissue samples can be taken for detailed biomolecular and histopathological examinations. Mice and rats have long served as the preferred 
species for biomedical research due to their anatomical, physiological, and genetic similarity to humans; spontaneous, drug-induced, metabolic alteration related and numerous genetically modified animal model have been developed for improving the understanding of the pathogenesis, prevention, and treatment of vascular abrasion and its comorbidities depend on their validity for representing human forms of vascular endothelial dysfunction. As an alternative, endothelial cells culture has been extensively described in the literature for in vitro assessment of oxidative stress, inflammation and proliferation (Le Brocq et al., 2008). The cell culture technique provides a path to explore wide variety of intracellular signalling pathways, with different purposes. However, these processes have restrictions related to phenotypic changes of the cells (Fadini and Avogaro, 2010). Hence, rodent models are preferred models that exhibit progressive vascular endothelial dysfunction is selected for identifying mechanisms involved in vascular endothelial dysfunction and to develop suitable therapeutic substances for its prevention.

\section{Diabetes-induced}

Diabetes mellitus is a pathological group of metabolic disorders characterized by chronic hyperglycemia which is mainly due to impairment of either insulin secretion and insulin action or both causing micro- and macro-vascular complications (Baig et al., 2019). Vascular injury due to uncontrolled hyperglycemia is a key reason behind diabetes associated with cardio- and cerebro-vascular disorders. Diabetes-associated vascular endothelial dysfunction involves multiple signaling pathways including elevation of polyol, protein kinase $\mathrm{C}$, hexosamine, pentose phosphate shunt which are overactive and are involved in diabetes-induced vascular endothelial dysfunction. Diabetes-induced oxidative stress also plays a crucial role in vascular endothelial dysfunction. Though multiple compounds at different doses have been identified, which are correlated with the clinical manifestation of diabetes mellitus-induced vascular endothelial dysfunction and are widely used to identify the potential pharmacological targets for vascular endothelial dysfunction.

\section{A) Streptozotocin-induced}

Streptozotocin, a naturally occurring agent obtained from Streptomyces acromogenes used to treat cancer of pancreatic islets of Langerhans but is highly toxic to the insulin-producing $\beta$-cells of the pancreas resulting in insulin depletion (Balakumar et al., 2008b). Streptozotocin at different doses of $40,50,55,60$, or $65 \mathrm{mg} / \mathrm{kg}$ intravenous or intraperitoneal route is widely used as an experimental model for inducing vascular endothelial dysfunction (Pieper et al., 1997; Zhu et al., 2011; Yin et al., 2014; Brahmanaidu et al., 2017; Kshirsagar et al., 2017; Azemi et al., 2020; Said, 2020). Within 72 hours of administration, a single dose of streptozotocin produces hyperglycemic effects but vascular endothelial dysfunction can be observed after 4-8 weeks. GLUT-2 present on the pancreatic cell uptakes streptozotocin which results in the alkylation of DNA and triggers activation of PARP, polyol, protein kinase $\mathrm{C}$, hexosamine, pentose phosphate shunt pathways, and overexpression of NOX2, leading to ROS/RNS generation and accumulation in the endothelial lining of blood vessel aggravating vascular endothelial dys-function. The induced vascular endothelial dysfunction is assessed for decreased aortic serum nitrate levels, T-BARS, GSH, NBT levels as well as increased phenylepinephrine-induced pre-contraction (Balakumar et al., 2009; Nie et al., 2019). Vascular endothelial dysfunction induced by intravenous administration of streptozotocin down-regulates the level of eNOS by producing superoxides and peroxynitrites and also alters GCH-1, responsible for $\mathrm{BH}_{4}$ synthesis which leads to the uncoupling of eNOS from its co-factor $\mathrm{BH}_{4}$ and alters $\mathrm{NO}$ bioavailability (Oelze et al., 2011).

Streptozotocin in rats $(30 \mathrm{mg} / \mathrm{kg}$ along with high fat and high sucrose diet), is associated with increased serum von Willibrand factor and decreased acetylcholine-induced relaxation, the content of aortic angiotensin converting enzymes, NOs, and expression of eNOS is decreased which are found responsible for reducing the elasticity of the vessels (Yang et al., 2011). Streptozotocin-induced hyperglycemia $(65 \mathrm{mg} / \mathrm{kg}$ intraperitoneal) is evaluated in vivo and in vitro for expression of calpain-1 protein by Western blot. Uncontrolled hyperglycemia persuades hypersecretion of proteolytic enzymes calpain and its isoforms which in turn activates apoptotic and necrotic factors and also alters NOS (Nie et al., 2019). Under streptozotocininduced hyperglycemia, HAEC (human aortic endothelial cell) is found with the expression of TRAF-6 (Tumor necrosis factor associated factor) and related adhesion factors like ICAM and VCAM. This TRAF-6 protein induces vascular endothelial dysfunction by expressing NFKB and AP-1-dependent signaling pathways (Liu et al., 2018). Transcripting factor AP-1 (activator protein) expression increases under the influence of various stimuli like stress, cytokines, growth factors which are associated with MAPK pathway activation. Streptozotocin is also responsible for decreasing the expression of sirtuin (SIRT-1) which is responsible for maintaining lipid and whole-body cholesterol homeostasis, decreased levels of SIRT-1 are associated with worsening of vascular endothelial dysfunction (Wu et al., 2018; Pal, 2019). Single intraperitoneal administration of streptozotocin not only tends to induce diabetes but also worsens vascular endothelial dysfunction (Ji et al., 2021). C75BL/6 transgenic mice at a single dose of 50 $\mathrm{mg} / \mathrm{kg}$ intraperitoneal for 5 consecutive days is not only found with elevated oxidative stress, inflammation, and aortic contractility but is also found to decrease SIRT-1 protein (Wu et al., 2018), In addition, BALB/c 
transgenic mice with intraperitoneal administration of streptozotocin is reported to up-regulate COX expression which results in increased release of proinflammatory mediators (Nacci et al., 2009).

While in alloxan-induced diabetes, oxidative stress is found to be associated with diabetes-induced complications but not associated with vascular endothelial dysfunction whereas in confirmed diabetic rats' level of eNOS and nNOS is altered and penile erection is reduced when compared to normal rats (Capellini et al., 2010). Despite biochemical alterations, histopathological changes including vacuolization in the endothelium, edema in the tunica adventia, and focal infiltration of tunica media are associated with streptozotocin administration to rats (Adel et al., 2014). Mechanism underlying streptozotocin-induced vascular endothelial dysfunction is depicted in Figure 1 and different doses and animal models for streptozotocin-induced vascular endothelial dysfunction are summarized in Table I.

\section{B) High fructose diet-induced}

Fructose, a simple ketonic dietary monosaccharide widely used to induce vascular endothelial dysfunction that correlates with clinical features for metabolic abnormalities as it does not only result in hyperglycemia but also alters the lipid profile by enhancing the levels of VLDL. In addition, the uric acid level in the blood is also affected. Thus, play a crucial role in cardiovascular disorders. A decrease in angiogenesis is one of the significant cell losses governed by a high fructose diet (Khitan and Kim, 2013). Fructose at different concentrations of $10,20,60$, and $65 \% \mathrm{w} / \mathrm{w}$, has been noted to induce diabetes and associated complications within 8-12 weeks. A high fructose diet to Sprague -Dawley rat is found to have increased plasma triglycerides, cholesterol, fat weight, blood pressure, and decreased glucose tolerance (Babacanoglu et al., 2013; Malakul et al., 2018). In addition, administration of fructose is associated with the increased level of endothelin-1, inflammatory mediators, adhesion molecules in the aorta. Phenylepinephrine and potassium chloride contractility are also exaggerated in rats (El-Bassossy et al., 2014). Furthermore, fructose causes an imbalance between superoxides, peroxynitrites, and antioxidants

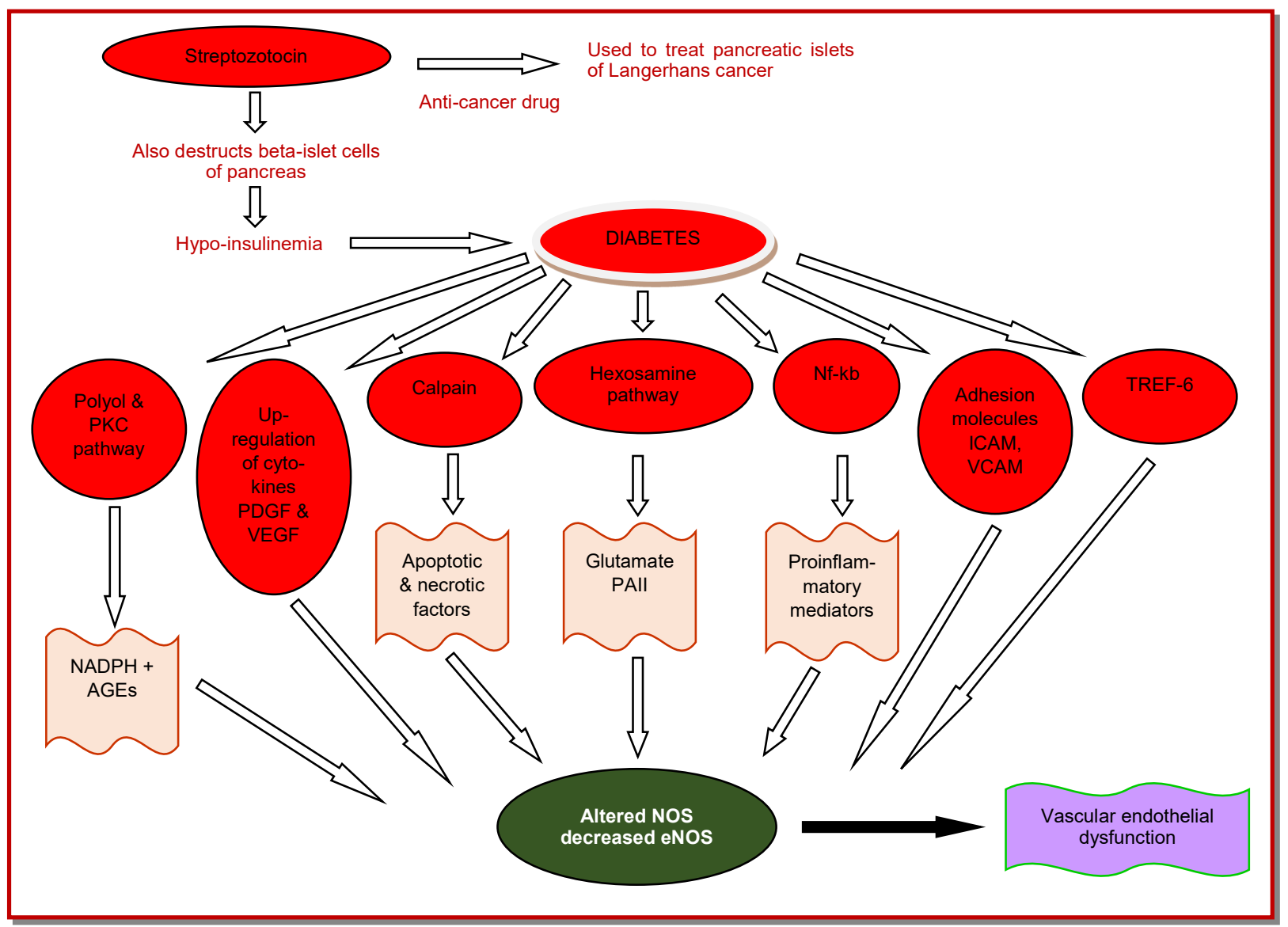

Figure 1. Mechanism underlying streptozotocin-induced vascular endothelial dysfunction.

PKc- protein kinase C signalling pathway; PDGF- platelet derived growth factor; VEGF- vascular endothelial growth factor; NfkB- nuclear factor kappa light chain enhancer of activated B cells; ICAM- intercellular adhesion molecules; VCAM- vascular cell adhesion molecule; TRAF-6- tumor necrosis factor (TNF) receptor associated factor-6; NADPH- nicotinamide adenine dinucleotide phosphate; AGE- advanced glycation end products; NOS- nitric oxide synthetase; NO-nitric oxide 


\section{Table I}

Streptozotocin-induced vascular endothelial disorders

\begin{tabular}{|c|c|c|c|c|c|}
\hline Species & $\begin{array}{l}\text { Dose and } \\
\text { route }\end{array}$ & Duration & Observations & Altered biomarkers & Reference \\
\hline $\begin{array}{l}\text { Male Sprague } \\
\text {-Dawley rats }\end{array}$ & $\begin{array}{l}65 \mathrm{mg} / \mathrm{kg} \text {, } \\
\text { intraperitone- } \\
\text { ally }\end{array}$ & single dose & $\begin{array}{l}\uparrow \text { blood glucose, total cholesterol, } \\
\text { triglyceride and LDL } \\
\text { impaired acetylcholine-induced } \\
\text { relaxation }\end{array}$ & $\begin{array}{l}\downarrow \text { aortic and serum } \mathrm{NO} \\
\text { level }\end{array}$ & $\begin{array}{l}\text { Bala- } \\
\text { kumar et } \\
\text { al., } 2008 \mathrm{~b}\end{array}$ \\
\hline $\begin{array}{l}\text { Male Sprague } \\
\text {-Dawley rats }\end{array}$ & $\begin{array}{l}65 \mathrm{mg} / \mathrm{kg} \text {, } \\
\text { intraperitone- } \\
\text { ally }\end{array}$ & single dose & $\uparrow$ levels of calpain-I, ROS/RNS & $\begin{array}{l}\downarrow \text { SOD, GSH-px } \\
\downarrow \text { aortic and serum NO } \\
\text { level, eNOS }\end{array}$ & $\begin{array}{l}\text { Nie et al., } \\
2019\end{array}$ \\
\hline $\begin{array}{l}\text { Male Wistar } \\
\text { rats }\end{array}$ & $\begin{array}{l}60 \mathrm{mg} / \mathrm{kg} \text {, } \\
\text { intraperitone- } \\
\text { ally }\end{array}$ & single dose & $\uparrow$ oxidative stress & $\begin{array}{l}\downarrow \text { vasorelaxation induced } \\
\text { by acetylcholine in the } \\
\text { aortic rings, NO levels } \\
\uparrow \text { eNOS uncoupling }\end{array}$ & $\begin{array}{l}\text { Zhu et al., } \\
2011\end{array}$ \\
\hline $\begin{array}{l}\text { Male Wistar } \\
\text { rats }\end{array}$ & $\begin{array}{l}60 \mathrm{mg} / \mathrm{kg} \text {, } \\
\text { intraperitone- } \\
\text { ally }\end{array}$ & single dose & $\uparrow$ oxidative stress, $\uparrow$ endothelin- 1 & $\uparrow$ eNOS uncoupling & $\begin{array}{l}\text { Said et al., } \\
2020\end{array}$ \\
\hline Wistar rats & $\begin{array}{l}60 \mathrm{mg} / \mathrm{kg} \\
\text { intravenous }\end{array}$ & single dose & $\begin{array}{l}\uparrow \text { NADPH oxidase, Nox- } 1 \text { and Nox- } 2 \\
\uparrow \text { eNOS uncoupling due to down- } \\
\text { regulation of GCH-1 } \\
\uparrow \text { MDA levels }\end{array}$ & $\begin{array}{l}\uparrow \text { ROS/RNS } \\
\text { Impaired acetylcholine- } \\
\text { induced vascular relaxa- } \\
\text { tion } \\
\downarrow \text { antioxidant }\end{array}$ & $\begin{array}{l}\text { Oelze et } \\
\text { al., } 2011\end{array}$ \\
\hline $\begin{array}{l}\text { Sprague- } \\
\text { Dawley rats }\end{array}$ & $\begin{array}{l}60 \mathrm{mg} / \mathrm{kg} \text {, } \\
\text { intraperitone- } \\
\text { ally }\end{array}$ & $\begin{array}{l}\text { single admin- } \\
\text { istration }\end{array}$ & $\begin{array}{l}\uparrow \text { NADPH oxidase } \\
\text { impaired acetylcholine- induced } \\
\text { endothelium-dependent relaxation }\end{array}$ & $\begin{array}{l}\downarrow \text { eNOS activity } \\
\uparrow \text { ROS/RNS } \\
\downarrow \text { SOD }\end{array}$ & $\begin{array}{l}\text { Ji et al., } \\
2021\end{array}$ \\
\hline $\begin{array}{l}\text { Male Wistar } \\
\text { rats }\end{array}$ & $\begin{array}{l}55 \mathrm{mg} / \mathrm{kg} \text {, } \\
\text { intraperitone- } \\
\text { ally }\end{array}$ & $\begin{array}{l}\text { single dose } \\
\text { once a week, } \\
\text { for } 8 \text { weeks }\end{array}$ & $\begin{array}{l}\text { up-regulation of NADPH oxidase, } \\
\text { NOX-2 } \\
\uparrow \text { TGF- } \beta \\
\uparrow \text { phenyl-epinephrine induced con- } \\
\text { traction }\end{array}$ & $\begin{array}{l}\downarrow \text { serum and aortic ni- } \\
\text { trate/nitrate levels } \\
\downarrow \text { eNOS }\end{array}$ & $\begin{array}{l}\text { Adel et al., } \\
2014\end{array}$ \\
\hline $\begin{array}{l}\text { Male Wistar } \\
\text { rats }\end{array}$ & $\begin{array}{l}55 \mathrm{mg} / \mathrm{kg} \text {, } \\
\text { intraperitone- } \\
\text { ally }\end{array}$ & $\begin{array}{l}\text { single dose } \\
\text { once a week } \\
\text { for } 8 \text { weeks }\end{array}$ & $\begin{array}{l}\downarrow \text { arginino succinate synthase, ar- } \\
\text { gininosuccinate lyase }\end{array}$ & $\downarrow$ GSH, SOD, GPx, $\downarrow$ eNOS & $\begin{array}{l}\text { Brah- } \\
\text { manaidu } \\
\text { et al., } 2017\end{array}$ \\
\hline $\begin{array}{l}\text { Male Sprague } \\
\text {-Dawley rats }\end{array}$ & $\begin{array}{l}55 \mathrm{mg} / \mathrm{kg} \\
\text { intravenous }\end{array}$ & $\begin{array}{l}\text { single admin- } \\
\text { istration }\end{array}$ & $\begin{array}{l}\uparrow \text { norepinephrine-induced vaso- } \\
\text { constriction } \\
\uparrow \text { ROS/RNS }\end{array}$ & $\begin{array}{l}\text { Impaired endothelial } \\
\text { dependent vaso- } \\
\text { relaxation } \\
\downarrow \text { SOD }\end{array}$ & $\begin{array}{l}\text { Pieper et } \\
\text { al., } 1997\end{array}$ \\
\hline $\begin{array}{l}\text { Male Wistar } \\
\text { rats }\end{array}$ & $\begin{array}{l}45 \mathrm{mg} / \mathrm{kg} \text {, } \\
\text { intraperitone- } \\
\text { ally }\end{array}$ & $\begin{array}{l}\text { single admin- } \\
\text { istration }\end{array}$ & $\begin{array}{l}\uparrow \mathrm{LDL} . \mathrm{TG}, \mathrm{TC} \\
\uparrow \text { Insulin resistance } \\
\uparrow \text { ROS/RNS/AGE's leading to un- } \\
\text { coupling of eNOS from its cofactors }\end{array}$ & $\begin{array}{l}\downarrow \text { serum NO level } \\
\downarrow \text { acetylcholine-induced } \\
\text { endothelium-dependent } \\
\text { relaxation }\end{array}$ & $\begin{array}{l}\text { Kshirsagar } \\
\text { et al., } \\
2017\end{array}$ \\
\hline $\begin{array}{l}\text { Male Wistar } \\
\text { rats }\end{array}$ & $\begin{array}{l}40 \mathrm{mg} / \mathrm{kg} \text {, } \\
\text { intraperitone- } \\
\text { ally }+ \text { high fat } \\
\text { diet }\end{array}$ & $\begin{array}{l}6 \text { weeks fed } \\
\text { with high fat } \\
\text { diet followed } \\
\text { by single } \\
\text { administra- } \\
\text { tion }\end{array}$ & $\begin{array}{l}\uparrow \text { overexpression of TNF-a, MCP-1, } \\
\text { and NF-kB P65 } \\
\uparrow \text { LDL, TG, TC } \\
\uparrow \text { LDL oxidation } \\
\uparrow \text { ICAM, VCAM, IL's }\end{array}$ & $\begin{array}{l}\downarrow \text { eNOS activity and NO } \\
\text { bioavailability } \\
\uparrow \text { ROS/RNS } \\
\text { uncoupling of eNOS from } \\
\text { its cofactors }\end{array}$ & $\begin{array}{l}\text { Yin et al., } \\
2014\end{array}$ \\
\hline $\begin{array}{l}\text { Male Sprague } \\
\text {-Dawley rats }\end{array}$ & $\begin{array}{l}40 \mathrm{mg} / \mathrm{kg} \text {, } \\
\text { intraperitone- } \\
\text { ally + high } \\
\text { fructose diet }\end{array}$ & $\begin{array}{l}4 \text { weeks fed } \\
\text { with high fat } \\
\text { diet followed } \\
\text { by single } \\
\text { administra- } \\
\text { tion }\end{array}$ & $\begin{array}{l}\uparrow \text { NADPH oxidase } \\
\uparrow \text { eNOS uncoupling } \\
\uparrow \text { AGE's } \\
\uparrow \text { free radicles }\end{array}$ & $\begin{array}{l}\downarrow \text { eNOS activity and NO } \\
\text { bioavailability } \\
\text { Impaired ACh induced } \\
\text { endothelium dependent } \\
\text { vasorelaxation }\end{array}$ & $\begin{array}{l}\text { Azemi et } \\
\text { al., } 2020\end{array}$ \\
\hline Rats & $\begin{array}{l}30 \mathrm{mg} / \mathrm{kg} \text {, } \\
\text { streptozotocin } \\
\text { intraperitone- } \\
\text { ally + high fat } \\
\text { and high glu- } \\
\text { cose diet }\end{array}$ & $\begin{array}{l}\text { single dose of } \\
\text { streptozoto- } \\
\text { cin followed } \\
\text { by fed for } 1 \\
\text { month }\end{array}$ & $\begin{array}{l}\uparrow \text { blood glucose, total cholesterol, } \\
\text { triglyceride, low-density lipoprotein } \\
\uparrow \mathrm{vWF} \\
\uparrow \text { phenyl-epinephrine induced con- } \\
\text { traction } \\
\uparrow \text { MDA levels }\end{array}$ & $\begin{array}{l}\downarrow \text { eNOS activity } \\
\downarrow \text { NO bioavailability } \\
\uparrow \text { levels of AGE's } \\
\uparrow \text { uncoupling of eNOS }\end{array}$ & $\begin{array}{l}\text { Yang et } \\
\text { al., } 2011\end{array}$ \\
\hline
\end{tabular}




\begin{tabular}{|c|c|c|c|c|c|}
\hline \multicolumn{6}{|c|}{ Table I } \\
\hline \multicolumn{6}{|c|}{ Streptozotocin-induced vascular endothelial disorders (cont.) } \\
\hline Species & $\begin{array}{l}\text { Dose and } \\
\text { route }\end{array}$ & Duration & Observations & Altered biomarkers & Reference \\
\hline C57BL/6 mice & $\begin{array}{l}50 \mathrm{mg} / \mathrm{kg} / \\
\text { day, intra- } \\
\text { peritoneally }\end{array}$ & $\begin{array}{l}\text { once every } \\
\text { day for } 5 \\
\text { consecutive } \\
\text { days }\end{array}$ & $\begin{array}{l}\uparrow \text { aortic contractility, p53 hyper- } \\
\text { acetylation } \\
\downarrow \text { SIRT1 protein }\end{array}$ & $\begin{array}{l}\uparrow \text { oxidative stress, inflam- } \\
\text { mation }\end{array}$ & $\begin{array}{l}\text { Wu et al., } \\
2018\end{array}$ \\
\hline C57BL/6 mice & $\begin{array}{l}50 \mathrm{mg} / \mathrm{kg} / \\
\text { day, intra- } \\
\text { peritoneally }\end{array}$ & $\begin{array}{l}\text { once every } \\
\text { day for } 5 \\
\text { consecutive } \\
\text { days }\end{array}$ & $\begin{array}{l}\uparrow \text { COX-2 expression } \\
\uparrow \mathrm{NFkB} \text { p56 } \\
\uparrow \mathrm{TXA} 2 \text {, PGE2 } \\
\uparrow \text { oxidative stress }\end{array}$ & $\begin{array}{l}\downarrow \text { NO bioavailability } \\
\downarrow \text { eNOS activity } \\
\downarrow \text { PPAR- } \gamma \text { and AMPK } \\
\text { expression }\end{array}$ & $\begin{array}{l}\text { Xu et al., } \\
2019\end{array}$ \\
\hline BALB/c mice & $\begin{array}{l}240 \mathrm{mg} / \mathrm{kg} \text {, } \\
\text { intraperito- } \\
\text { neally }\end{array}$ & $\begin{array}{l}\text { single admin- } \\
\text { istration }\end{array}$ & $\begin{array}{l}\text { impaired acetylcholine-induced } \\
\text { vascular relaxation } \\
\uparrow \text { expression of TNF-a, NFKB } \\
\uparrow \text { PGF-1 } a\end{array}$ & $\begin{array}{l}\uparrow \text { expression of pro- } \\
\text { inflammatory signals } \\
\uparrow \text { COX-2 expression }\end{array}$ & $\begin{array}{l}\text { Nacci et } \\
\text { al., } 2009\end{array}$ \\
\hline
\end{tabular}

like SOD, GSH tends to create oxidative stress in the endothelial lining of the blood vessel which leads to impaired vasorelaxation (Kho et al., 2014; Shawky et al., 2014). Regarding vascular structural changes, fructose induces thickening of the endothelial wall due to the release and accumulation of various adhesion molecules, along with hyperplasia (Zhai et al., 2017) (Table II).

Taken together, streptozotocin- and fructose-induced models are widely used for pharmacological evaluation of vasoprotective agents against diabetes-associated vascular endothelial dysfunction. Streptozotocin dose ranges from 50 to $65 \mathrm{mg} / \mathrm{kg} /$ day intraperitoneally. Dose selection depends entirely upon the duration of study and frequency of drug administration. Streptozotocin $50 \mathrm{mg} / \mathrm{kg} /$ day intraperitoneal is required to administer once daily for 5 consecutive days as compared to a single administration of $65 \mathrm{mg} / \mathrm{kg} /$ day intraperitoneally. In case of fructose is employed ranging from 10 to $65 \%$ oral solution, again it also depends upon the duration of study as 60 and $65 \%$ oral solution of fructose are given for 8 weeks as compared to 10 and $20 \%$ oral solution for 12 weeks. However, their effects on biomarkers are the same irrespective of dose. In our opinion, for short-term studies, a high dose is preferred and for chronic studies, small and repetitive doses are preferred. Regarding selection among streptozotocin and fructose, streptozotocin is used for induction of type 1 diabetes, and fructose is preferred for induction of type 2 diabetes.

\section{Doxorubicin-induced}

Doxorubicin (adriamycin) is an anti-cancer drug which belongs to anthracycline class of antibiotic. It is used in treating a wide variety of cancer but due to toxicities like cardiomyopathy and nephropathy, its clinical use is constrained (Carvalho et al., 2009). Excessive generation of mitochondrial ROX impairs endothelial functioning on exposure to doxorubicin. Doxorubicin-treated aortic ring shows abnormal function, induce vascular stress and causes apoptosis of endothelial lining. It also down -regulates the expression of NRF-2 which plays an important role in the protection of vascular endothelial dysfunction (Wang et al., 2015). Doxorubicin $20 \mathrm{mg} / \mathrm{kg}$ intraperitoneally on single administration in mouse model decreases the contractile responses to phenylephrine, along with attenuation of relaxant responses to acetylcholine. In addition, decrease in the aortic and serum nitrate, SOD, and GSH levels were observed (Olukman et al., 2009). Administration of doxorubicin (5 mg/ $\mathrm{kg}$ ) for 2-4 weeks is associated with vascular endothelial dysfunction by indirectly altering the level of NO through declining l-arginine (Li et al., 2019). In addition, loss of endothelium function due to marked increase in ROS/RNS is observed in doxorubicin-treated transgenic C57BL/ 6 mice, as a key role in establishing vascular endothelial dysfunction (Clayton et al., 2020). Doxorubicin not only alters the biochemical mediators but also leads to histopathological changes which include thickening of blood vessels, inflammatory infiltration, loss of vascular integrity, and vacuolization of the endothelial cells when compare to the doxorubicin-untreated aortic block (Li et al., 2019; Table III). To conclude, doxorubicin is used as an experimental tool within the dose ranges from 5 to $20 \mathrm{mg} / \mathrm{kg}$, intraperitoneal, but it's worth mentioning that 5 or 10 $\mathrm{mg} / \mathrm{kg}$ intraperitoneal is used for genetically engineered models i.e. C57BL/6 mice model. However, for Wistar rats, $20 \mathrm{mg} / \mathrm{kg}$ intraperitoneal of doxorubicin is employed to induce vascular endothelial dysfunction. All these show similarities in altered biomarkers.

\section{Nicotine-induced}

Nicotine exposure through cigarette smoking is one of the major factors playing a crucial role in modulating vascular activity leading to the development of endothelium dysfunction which is associated with various life-threatening cardiovascular disorders. Nicotine 


\begin{tabular}{|c|c|c|c|c|c|}
\hline \multicolumn{6}{|c|}{ Table II } \\
\hline \multicolumn{6}{|c|}{ Fructose-induced vascular endothelial disorders } \\
\hline Species & $\begin{array}{l}\text { Dose and } \\
\text { route }\end{array}$ & Duration & Observations & Altered biomarkers & Reference \\
\hline $\begin{array}{l}\text { Male Sprague- } \\
\text { Dawley rats }\end{array}$ & $\begin{array}{l}10 \% \text { orally } \\
\text { ad libitum }\end{array}$ & 12 weeks & $\begin{array}{l}\uparrow \text { blood glucose, total cholester- } \\
\text { ol, triglyceride and LDL } \\
\downarrow \text { acetylcholine-induced vaso- } \\
\text { relaxation }\end{array}$ & $\begin{array}{l}\downarrow \text { aortic and serum NO level, } \\
\text { eNOS, p-eNOS } \\
\uparrow \text { ROS/RNS }\end{array}$ & $\begin{array}{l}\text { Malakul et } \\
\text { al., } 2018\end{array}$ \\
\hline $\begin{array}{l}\text { Male Kunming } \\
\text { mice }\end{array}$ & $\begin{array}{l}20 \% \text { orally } \\
\text { ad libitum }\end{array}$ & 8 weeks & $\begin{array}{l}\uparrow \text { serum total cholesterol, tri- } \\
\text { glyceride, LDL-C, TXA } A_{2} \text { and } \\
\text { endothelin- } 1 \text {, AST and ALT } \\
\text { thickening of the endothelial } \\
\text { wall, accumulation of adhesion } \\
\text { molecules and hyperplasia }\end{array}$ & $\begin{array}{l}\downarrow \text { HDL-C, } \mathrm{PGI}_{2} \text { serum and } \\
\text { aortic eNOS levels } \\
\downarrow \text { SOD and GSH }\end{array}$ & $\begin{array}{l}\text { Zhai et al., } \\
2017\end{array}$ \\
\hline Male rats & $\begin{array}{l}65 \% \text { orally } \\
\text { ad libitum }\end{array}$ & 8 weeks & $\begin{array}{l}\uparrow \text { fat weight, blood pressure, } \\
\text { plasma triglyceride, total choles- } \\
\text { terol levels, and oral glucose } \\
\text { tolerance }\end{array}$ & $\begin{array}{l}\downarrow \text { aortic and serum NO level, } \\
\text { eNOS, p-Enos } \\
\text { increased ROS/RNS }\end{array}$ & $\begin{array}{l}\text { (Kho et al., } \\
\text { 2014) }\end{array}$ \\
\hline $\begin{array}{l}\text { Male Wistar } \\
\text { rats }\end{array}$ & $\begin{array}{l}10 \% \text { orally } \\
\text { ad libitum }\end{array}$ & 6 weeks & $\begin{array}{l}\uparrow \text { serum levels of glucose, insu- } \\
\text { lin, uric acid, TNFa, lipids, AG- } \\
\text { Es }\end{array}$ & $\begin{array}{l}\text { exaggerated contractility to } \\
\text { phenylepinephrine and } \mathrm{KCl} \\
\text { and impaired relaxation to } \\
\text { acetylcholine }\end{array}$ & $\begin{array}{l}\text { El-Bassossy } \\
\text { et al., } 2014\end{array}$ \\
\hline $\begin{array}{l}\text { Male Sprague- } \\
\text { Dawley rats }\end{array}$ & $\begin{array}{l}60 \% \text { orally } \\
\text { ad libitum }\end{array}$ & 8 weeks & $\begin{array}{l}\downarrow \text { fasting glucose, GSH and } \\
\text { MDA levels, serum total choles- } \\
\text { terol, LDL-C, C-reactive protein } \\
\text { level and LDH }\end{array}$ & $\begin{array}{l}\downarrow \text { aortic and serum NO level, } \\
\text { eNOS, p-Enos } \\
\uparrow \text { ROS/RNS } \\
\uparrow \text { phenylepinephrine-induce } \\
\text { contraction }\end{array}$ & $\begin{array}{l}\text { Shawky et al., } \\
2014\end{array}$ \\
\hline Male rats & $\begin{array}{l}10 \% \text { and } \\
20 \% \text {, orally } \\
\text { ad libitum }\end{array}$ & 12 weeks & $\begin{array}{l}\uparrow \text { plasma triglyceride, VLDL, } \\
\text { cholesterol, insulin and glucose } \\
\text { levels, but not body weights }\end{array}$ & $\begin{array}{l}\text { impaired NO mediated } \\
\text { relaxation } \\
\text { alters vascular reactivity to } \\
\text { insulin, endothelin-1 in } \\
\text { conjunction with insulin } \\
\text { receptor substrate-1, endo- } \\
\text { thelial nitric oxide synthase, } \\
\text { inducible NOS mRNA/ } \\
\text { proteins levels in aorta }\end{array}$ & $\begin{array}{l}\text { Babacanoglu } \\
\text { et al., } 2013\end{array}$ \\
\hline
\end{tabular}

\section{Table III}

\section{Doxorubicin-induced vascular endothelial disorders}

\begin{tabular}{|c|c|c|c|c|}
\hline Species & Dose and route & Duration & Altered biomarkers & Reference \\
\hline $\begin{array}{l}\text { Male C57BL/ } 6 \text { mice } \\
\text { model }\end{array}$ & $\begin{array}{l}10 \mathrm{mg} / \mathrm{kg} \text {, } \\
\text { intraperitone- } \\
\text { ally }\end{array}$ & 4 weeks & $\begin{array}{l}\text { impairs endothelial function } \\
\uparrow \text { mitochondrial reactive oxygen species (ROS) }\end{array}$ & $\begin{array}{l}\text { Clayton et al., } \\
2020\end{array}$ \\
\hline $\begin{array}{l}\text { Wild type male mice } \\
\text { C57BL/ } 6 \text { model }\end{array}$ & $\begin{array}{l}5 \mathrm{mg} / \mathrm{kg} \text {, intra- } \\
\text { peritoneally }\end{array}$ & $\begin{array}{c}2 \text { or } 4 \\
\text { weeks }\end{array}$ & $\begin{array}{l}\downarrow \text { level of arginine-NO metabolite } \\
\uparrow \text { level of vascular damage } \\
\downarrow \text { vascular relaxation, vascular NO generation } \\
\uparrow \text { blood pressure apoptosis, and oxidative stress }\end{array}$ & Li et al., 2019 \\
\hline Wistar rats & $\begin{array}{l}20 \mathrm{mg} / \mathrm{kg} \text {, } \\
\text { intraperitone- } \\
\text { ally }\end{array}$ & & $\begin{array}{l}\downarrow \text { NO formation, eNOS and iNOS } \\
\downarrow \text { contractile responses to phenylephrine, but also attenu- } \\
\text { ated the relaxant responses to acetylcholine }\end{array}$ & $\begin{array}{l}\text { Olukman et al., } \\
2009\end{array}$ \\
\hline $\begin{array}{l}\text { Adult male Sprague } \\
\text {-Dawley rats }\end{array}$ & $\begin{array}{l}15 \mathrm{mg} / \mathrm{kg} \text {, } \\
\text { intraperitone- } \\
\text { ally }\end{array}$ & 14 days & $\begin{array}{l}\uparrow \text { ROS/RNS } \\
\uparrow \text { MDA } \\
\uparrow \text { expression of inflammatory mediators (ICAM, VCAM, } \\
\text { TGF- } \beta, \text { VEGF) } \\
\uparrow \text { apoptosis altered vascular integrity and vascular tone }\end{array}$ & $\begin{array}{l}\text { Wang et al., } \\
2015\end{array}$ \\
\hline
\end{tabular}




\begin{tabular}{|c|c|c|c|c|c|}
\hline \multicolumn{6}{|c|}{ Table IV } \\
\hline \multicolumn{6}{|c|}{ Nicotine-induced vascular endothelial disorders } \\
\hline Species & $\begin{array}{l}\text { Dose and } \\
\text { route }\end{array}$ & Duration & Pathways & Altered biomarkers & Reference \\
\hline Male mice & $\begin{array}{l}2 \mathrm{~g} / \mathrm{kg} / \\
\text { day, intra- } \\
\text { peritoneally }\end{array}$ & 2 weeks & $\begin{array}{l}\uparrow \text { NLRP-3 inflammasome } \\
\downarrow \text { ZO- } 1 \text { and ZO-2 epithelial and endo- } \\
\text { thelial receptors }\end{array}$ & $\begin{array}{l}\uparrow \text { cleavage of pro-caspase- } 1 \\
\uparrow \text { production of IL- } 1 \beta \\
\text { lysosomal release of cathepsin B }\end{array}$ & $\begin{array}{l}\text { Zhang et } \\
\text { al., } 2019\end{array}$ \\
\hline $\begin{array}{l}\text { Male Spra- } \\
\text { gue-Dawley } \\
\text { rats }\end{array}$ & $\begin{array}{l}0.6 \mathrm{mg} / \mathrm{kg} \text {, } \\
\text { intraperito- } \\
\text { neally }\end{array}$ & 28 days & $\begin{array}{l}\uparrow \text { oxidative stress, low NO bioavaila- } \\
\text { bility } \\
\uparrow \text { accumulation of vascular adhesion } \\
\text { molecules vascular wall thickening } \\
\text { inflammatory response }\end{array}$ & $\begin{array}{l}\text { loss of vascular integrity } \\
\uparrow \text { vascular remodelling and oxi- } \\
\text { dative stress } \\
\uparrow \text { phenylephrine-induced vaso- } \\
\text { constriction }\end{array}$ & $\begin{array}{l}\text { Si et al., } \\
2017\end{array}$ \\
\hline ApoE-/- mice & $\begin{array}{l}0.1 \mathrm{mg} / \mathrm{mL} \text {, } \\
\text { orally } \\
\text { ad libitum }\end{array}$ & 12 weeks & $\begin{array}{l}\uparrow \text { ERK1/2 signalling } \\
\uparrow \text { expression of adhesion molecules } \\
\text { ICAM and VCAM } \\
\text { promoting adherence of leukocytes } \\
\uparrow \text { NF-KB-dependent expression }\end{array}$ & $\begin{array}{l}\text { larger atherosclerotic plaques } \\
\text { loss of vascular integrity } \\
\uparrow \text { vascular remodelling and oxi- } \\
\text { dative stress }\end{array}$ & $\begin{array}{l}\text { Qin et al., } \\
2020\end{array}$ \\
\hline $\begin{array}{l}\text { Sprague- } \\
\text { Dawley rats } \\
\text { with diet- } \\
\text { induced } \\
\text { obesity }\end{array}$ & $\begin{array}{l}100 \mathrm{mg} / \mathrm{L} \text {, } \\
\text { orally } \\
\text { ad libitum }\end{array}$ & 20 weeks & $\begin{array}{l}\uparrow \mathrm{TNF} \alpha \text {, interleukin } 1 \beta, \\
\uparrow \mathrm{CD} 36 \\
\uparrow \text { proinflammatory genes } \\
\uparrow \mathrm{NADPH} \text { oxidase }\end{array}$ & $\begin{array}{l}\uparrow \text { systolic blood pressure, aortic } \\
\text { superoxide production } \\
\uparrow \text { impaired endothelial nitric } \\
\text { oxide synthase and } \\
\downarrow \text { endothelium-dependent relax- } \\
\text { ation to acetylcholine }\end{array}$ & $\begin{array}{l}\text { Liu et al., } \\
2017\end{array}$ \\
\hline $\begin{array}{l}\text { male Wistar } \\
\text { rats }\end{array}$ & $\begin{array}{l}2 \mathrm{mg} / \mathrm{kg} / \\
\text { day, } \\
\text { intraperito- } \\
\text { neally }\end{array}$ & 4 weeks & $\begin{array}{l}\uparrow \text { serum cholesterol, triglycerides and } \\
\text { high-density lipoprotein. } \\
\downarrow \text { expression of mRNA for p22phox } \\
\text { and endothelial nitric oxide synthase }\end{array}$ & $\begin{array}{l}\text { loss integrity of vascular endo- } \\
\text { thelium } \\
\uparrow \text { serum TBARS } \\
\uparrow \text { aortic superoxide anion con- } \\
\text { centration }\end{array}$ & $\begin{array}{l}\text { Chak- } \\
\text { karwar, } \\
2011\end{array}$ \\
\hline $\begin{array}{l}\text { Wistar albi- } \\
\text { no rats }\end{array}$ & $\begin{array}{l}2 \mathrm{mg} / \mathrm{kg} / \\
\text { day, } \\
\text { intraperito- } \\
\text { neally }\end{array}$ & 4 weeks & $\begin{array}{l}\uparrow \text { generation of ROS/RNS } \\
\downarrow \text { acetylcholine-induced endothelium } \\
\text {-dependent relaxation }\end{array}$ & $\begin{array}{l}\downarrow \text { aortic and serum nitrite/nitrate } \\
\uparrow \text { serum TBARS } \\
\uparrow \text { generation of ROS } \\
\text { impairing endothelial integrity }\end{array}$ & $\begin{array}{l}\text { Balakumar } \\
\text { et al., 2008c }\end{array}$ \\
\hline $\begin{array}{l}\text { Wistar albi- } \\
\text { no rats }\end{array}$ & $\begin{array}{l}2 \mathrm{mg} / \mathrm{kg} / \\
\text { day, } \\
\text { intraperito- } \\
\text { neally }\end{array}$ & 4 weeks & $\begin{array}{l}\downarrow \text { expression of PPARY } \\
\uparrow \text { vascular oxidative stress } \\
\uparrow \text { activation of NADPH oxidase } \\
\uparrow \text { xanthine oxidase } \\
\uparrow \text { mononuclear leukocyte adhesion } \\
\uparrow \text { expression of adhesion molecules } \\
\text { such as VCAM- } 1 \text { and ICAM }\end{array}$ & $\begin{array}{l}\downarrow \text { expression of eNOS } \\
\uparrow \text { the generation of ROS } \\
\text { impairing endothelial integrity }\end{array}$ & $\begin{array}{l}\text { Taneja et } \\
\text { al., } 2013\end{array}$ \\
\hline
\end{tabular}

aggravates multiple inflammatory and metabolic processes. The various vascular endothelial dysfunction is oxidative injury, endothelial damage and dysfunction, enhanced thrombosis, chronic inflammation, hemodynamic stress, adverse effects on blood lipids, insulin resistance and diabetes, reduced oxygen delivery by red blood cells, and arrhythmogenesis. The doses of nicotine are $2 \mathrm{mg} / \mathrm{kg}$ (Balakumar et al., 2008c) or $0.6 \mathrm{mg} / \mathrm{kg}$ (Si et al., 2017) for 28 days via intraperitoneal route to induce vascular endothelial dysfunction in experimental animal models. The induced vascular endothelial dysfunction is evaluated for various parameters like serum nitrate, aortic nitrate, TBARS, GSH, and SOD levels. Increased expression of TNF- $\alpha$, interleukin $1 \beta$, $\mathrm{CD} 36, \mathrm{NADPH}^{+}$are responsible for the production of ROS/RNS which in turn creates a burden on the endothelium of the vessel, which plays a key role in progressing vascular endothelial dysfunction. This oxi- dative stress induced by nicotine alters the vascular integrity, elasticity of blood vessels and increases phenylepinephrine-induced contraction (Chakkarwar, 2011). Chronic exposure to nicotine causes angiogenesis -mediated inflammation, ischemia, atherosclerosis by binding to a7 nAchR's. In experimental mice model, nicotine is also found responsible for expressing NLRP3 inflammasomes which in turn cleaves pro-caspase-1 and pro-inflammatory mediators, generating ROS/RNS via down-regulation of special endothelial receptors $\mathrm{ZO}$ -1 and ZO-2 which cause macro- and micro-vascular injuries (Zhang et al., 2019). Nicotine also accounts for the up-regulation of ADMA which is an endogenous eNOS inhibitor contributing to increased vasoconstriction (Taneja et al., 2013). Not only endothelial cells but adipocytes have also been reported responsible for vascular injuries as they are found to secrete various inflammatory cytokines (IL-1 $\beta$, IL-6, TNF- $\alpha$, NF-kb,) 
and adhesion molecules (ICAMS, VCAMS) selectively in the presence of nicotine. Persistent exposure of nicotine acts through pre-ganglionic nerve fibers leading to activation of the sympathetic system, increasing epinephrine levels which ultimately constricts blood vessel, increase cardiac output and creates a burden on the endothelial layer which results in vascular endothelial dysfunction. The endothelial lining of the aortic block of nicotine-treated rats is destructed, and vascular integrity loss is also observed due to the inflammatory infiltration (Si et al., 2017). Concomitant administration of nicotine and a high-fat diet to rats is associated with an increase in diameter and the intense destruction of the endothelial (Liu et al., 2017) suggesting the synergistic effect of nicotine and high-fat diet in the induction of vascular complications. Table IV concludes induction of vascular endothelial dysfunction at different doses of nicotine.

Considering all the studies, it may be concluded that for pharmacological evaluation of vasoprotective agents, nicotine-induced vascular endothelial dysfunction models are widely explored as it provides the clinical relevancy for lifestyle-related vascular endothelial dysfunction. Regarding dose selection of nicotine, it ranges from 0.6 to $2 \mathrm{mg} / \mathrm{kg}$ / day that mainly depending upon the frequency of administration and the duration of the study (2-4 weeks; Table IV). Additionally, it also depends upon the species that have been included in the study as Apo E-/- mice established vascular endothelial dysfunction within 12 weeks of orally administering low dose of nicotine $(0.1 \mathrm{mg} / \mathrm{mL}$ ) (Qin et al., 2020). Though a high dose is used for the shorter duration studies, a high dose is associated with mortality. Thus, it may be suggested that small and repetitive doses should be chosen for chronic studies.

\section{Arsenic-induced}

The endothelial cells of the aortic arch of the experimental rats exposed to arsenic-contaminated drinking water for 3 months at the dose of 10 or $50 \mathrm{mg} / \mathrm{L}$ are found to be seriously damaged (Guo et al., 2020). The levels of apoptotic factors, vWF, iNOS are elevated, while the level of PEDF (pigment epithelial-derived factor) which helps in maintaining endothelial function is decreased (Guo et al., 2020). Arsenic exposure leads to endothelial cell damage due to the release of apoptotic caspase-3. The detrimental role of arsenic is further supported by a study that reported that after 90 days of consecutive exposure to $100 \mathrm{ppm}$ arsenic through drinking water, rats are found to have increased levels of adhesion molecules, cytokines, and inflammatory mediators while reduced levels of eNOS, iNOS mRNA expression, NO production which leads to vascular endothelial dysfunction-associated cardiovascular disorders (Kesavan et al., 2014). Arsenic has also been noted to be involved in the activation of NADPH oxidase that tends to generate ROS/RNS in the blood vessels ultimately destroying its innermost layer (Ellinsworth, 2015). The detrimental role of arsenic has been further confirmed by the studies stating that exposure to arsenic for 2 weeks at a dose of $1.5 \mathrm{mg} / \mathrm{kg}$ relatively increases the expression of TNF-a, ROS/RNS which worsens the vascular endothelial dysfunction (Kaur et al., 2010; Jyoti et al., 2016). Histopathology studies from Wistar rats exposed to arsenic revealed that arsenic exposure is associated with agglutination of erythrocytes followed by infiltration of mononuclear cells, cytoplasmic swelling along morphological changes in nuclei of aortic endothelial cells (Guo et al., 2019b). Observed data from different studies in Table $\mathrm{V}$ express that exposure to arsenic at different doses ranging from $2-50 \mathrm{mg} / \mathrm{L}$ for $3-$ 6 months via drinking water is a widely used model for chronic study while the exposure through $100 \mathrm{mg} / \mathrm{L}$ arsenic in drinking water for 90 consecutive days is an alternative study with relevant alterations in biomarkers. As high doses selected for short-term studies are associated with increased mortality. Therefore, low doses selected for long-term chronic studies are prefered to reduce the mortality and toxicity index. Administration of $1.5 \mathrm{mg} / \mathrm{kg}$ of arsenic through intraperitoneal route for 2 weeks is preferred for short-term study.

\section{Bisphenol-A-induced}

An industrial chemical, bisphenol-A, is an endocrine imitating chemical that hampers the normal physiology. Bisphenol-A exposure to the animal (Wild-type CD1 mice) is associated with increased oxidative stress and it contributes to worsening vascular endothelial functioning by mediating the release of inflammatory mediators, up-regulating M-1 macrophage, and activating CAM-KII. Activation of CAM-KII is further associated with the release of apoptotic and necrotic factors which damages endothelial cells of blood vessels (Reventun et al., 2020). Thus, bisphenol-A is considered an important factor in the induction and progression of vascular endothelial dysfunction. Experimental rat model reveals that administered of bisphenol-A 0.1 $\mathrm{mg} / \mathrm{kg} /$ day for 60 consecutive days, inhibits acetylcholine-induced relaxation and also associated with NOS and COX blockage, increased levels of NADP+ with elevating the level of ROS/RNS resulting in impaired endothelial function. The model also states the involvement of prostanoids, increase levels of which results in vasoconstriction (Friques et al., 2020). It is worthwhile to note that administration of bisphenol-A through contaminated drinking water $(4 \mathrm{nM}$ to $400 \mu \mathrm{M})$ for 30 days to CD11 mice is found to increase Ang-II expression which uncouples eNOS from its co-factors like FMN, BH-4, promoting oxidative stress. Wistar rats exposed to bisphenol-A at a dose of $35 \mathrm{mg} / \mathrm{kg}$ via oral route for long-term study (60 days) decrease acetylcholine-induced relaxation by increasing oxidative stress and lipid peroxidation (Rameshrad et al., 2018). In addition, the concentration of calcium/calmodulin- 


\begin{tabular}{|c|c|c|c|c|c|}
\hline \multicolumn{6}{|c|}{ Table V } \\
\hline \multicolumn{6}{|c|}{ Arsenic-induced vascular endothelial disorders } \\
\hline Species & $\begin{array}{l}\text { Dose and } \\
\text { route }\end{array}$ & Duration & Pathways & Altered biomarkers & Reference \\
\hline $\begin{array}{l}\text { Male Wistar } \\
\text { rats }\end{array}$ & $\begin{array}{l}2,10, \text { and } 50 \\
\mathrm{mg} / \mathrm{L}, \text { orally } \\
\text { ad libitum }\end{array}$ & $\begin{array}{l}3-6 \\
\text { months }\end{array}$ & $\begin{array}{l}\downarrow \text { pigment epithelium-derived } \\
\text { factor } \\
\uparrow \text { protein levels of Fas, FasL, P53, } \\
\text { and phospho-p38 } \\
\uparrow \text { ROS/RNS }\end{array}$ & $\begin{array}{l}\downarrow \text { serum nitric oxide, von Wil- } \\
\text { lebrand factor, and nitric oxide } \\
\text { synthase }\end{array}$ & $\begin{array}{l}\text { Guo et al., } \\
\text { 2019a; Guo } \\
\text { et al., } 2020\end{array}$ \\
\hline $\begin{array}{l}\text { Male Wistar } \\
\text { rats }\end{array}$ & $\begin{array}{l}100 \mathrm{mg} / \mathrm{L} \text {, } \\
\text { orally } \\
\text { ad libitum }\end{array}$ & $\begin{array}{l}90 \text { con- } \\
\text { secutive } \\
\text { days }\end{array}$ & $\begin{array}{l}\downarrow \text { acetylcholine induced relaxation, } \\
\text { aortic eNOS at the levels, NO pro- } \\
\text { duction } \\
\uparrow \text { production of pro-inflammatory } \\
\text { mediators (IL-1 } \beta \text {, IL- } 6, \text { MCP- } 1 \text {, } \\
\text { VCAM, ICAM) and serum C- } \\
\text { reactive protein }\end{array}$ & $\begin{array}{l}\uparrow \text { phenylephrine } \\
\uparrow \text { eNOS and iNOS mRNA ex- } \\
\text { pression } \\
\downarrow \text { NO bioavailability and produc- } \\
\text { tion }\end{array}$ & $\begin{array}{l}\text { Kesavan et } \\
\text { al., } 2014\end{array}$ \\
\hline $\begin{array}{l}\text { Wistar rats } \\
\text { of either sex }\end{array}$ & $\begin{array}{l}1.5 \mathrm{mg} / \mathrm{kg} / \\
\text { day, intraper- } \\
\text { itoneally }\end{array}$ & 2 weeks & $\begin{array}{l}\uparrow \text { TNF- } \\
\downarrow \text { l-arginine converting enzyme }\end{array}$ & $\begin{array}{l}\uparrow \text { oxidative stress, TBARS } \\
\text { abrogated acetylcholine-induced } \\
\text { vasorelaxation } \\
\downarrow \text { serum nitrite/ nitrate concen- } \\
\text { tration, glutathione level }\end{array}$ & $\begin{array}{l}\text { Kaur et al., } \\
2010\end{array}$ \\
\hline $\begin{array}{l}\text { Wistar rats } \\
\text { of either sex }\end{array}$ & $\begin{array}{l}1.5 \mathrm{mg} / \mathrm{kg} / \\
\text { day, intraper- } \\
\text { itoneally }\end{array}$ & 2 weeks & $\begin{array}{l}\uparrow \text { TNF- } \alpha \\
\downarrow \text { l-arginine converting enzyme }\end{array}$ & $\begin{array}{l}\uparrow \text { oxidative stress, super oxides } \\
\downarrow \text { eNOS expression, } \\
\downarrow \text { serum nitrite/ nitrate concen- } \\
\text { tration, glutathione level }\end{array}$ & $\begin{array}{l}\text { Jyoti et al., } \\
2016\end{array}$ \\
\hline
\end{tabular}

dependent protein kinase II a in $10 \mathrm{nM}$ bisphenol-Atreated CD11 mice increases in aortic endothelial cells when assessed by microarray analysis which increases the generation of ROS/RNS (Saura et al., 2014). To summarize, bisphenol-A is continuously administered for at least 4 weeks to induce vascular endothelial dysfunction, which may be extended to 16 weeks depending upon the species to species and route of administration. Wild-type CD1 mice exposed to different doses ranging from $4 \mathrm{nM}$ to $400 \mu \mathrm{M}$ of bisphenol-A in the drinking shows the clinical signs of vascular endothelial dysfunction after 30 days. On the other hand, $35 \mathrm{mg} /$ $\mathrm{kg}$ / day orally for 2 months induced vascular endothelial dysfunction in Wistar rats, suggesting that a low dose is sufficient for genetically modified mice as compared to Wistar rats (Table VI).

\section{Hypertension}

Hypertension is one of the independent contributing risk factors for increasing vascular endothelial dysfunction and associated vital organ dysfunction in the initial stages, while the progressed vascular endothelial dysfunction plays a crucial role in worsening hypertension therefore, it has been stated that hypertension and vascular endothelial dysfunction are interlinked. Hypertension alters the normal physiological balance between vasorelaxant and vasoconstrictor factors and stimulates the vascular endothelial cells to release the vasoactive component like Ang-II, inflammatory cytokines, adhesion molecules (CAM, VCAM) resulting in vasoconstriction, thrombosis, and coagulation. A study revealed that hypertension, as well as vascular endothelial dysfunction, is responsible for promoting atherosclerosis. The formation of atherosclerotic plaques interferes with the free flow of the blood (Taddei et al., 2001).

\section{A) Deoxycorticosterone induced}

Deoxycorticosterone acetate is a mineralocorticoid that maintains electrolyte and fluid balance. It is used experimentally in animals to induce hypertension (Schenk and McNeill, 1992). Intramuscular administration of deoxycorticosterone on day $1(20 \mathrm{mg} / \mathrm{kg})$, day $14(10$ $\mathrm{mg} / \mathrm{kg}$ ) to dog (Ueno et al., 1988) shows results similar to that of rat exposed to deoxycorticosterone subcutaneously at the dose of $50 \mathrm{mg} / \mathrm{kg}$ twice a week (Basso et al., 1985). Deoxycorticosterone subcutaneous injection at 20 (Han et al., 2019) or $50 \mathrm{mg} / \mathrm{kg}$ (Niazi et al., 2020) has shown hypertension-induced vascular endothelial dysfunction by decreasing eNOS bioavailability and altered vascular tone (Kubacka et al., 2019). Deoxycorticosterone-induced hypertension is associated with vascular endothelial dysfunction by the generation of ROS/RNS in the blood vessels that hampers the normal physiological balance between vasoconstrictory and vasodilatory factors. In addition, administration of deoxycorticosterone is associated with increased expression of Ang-II and NADPH oxidase.

Mitochondrial SIRT-3 and SIRT-6 are deacetylase proteins that are expressed in cardiomyocytes and play a crucial role in regulating metabolic and antioxidant function. Interestingly, in deoxycorticosterone-induced 


\begin{tabular}{|c|c|c|c|c|c|}
\hline \multicolumn{6}{|c|}{ Table VI } \\
\hline \multicolumn{6}{|c|}{ Bisphenol A-induced vascular endothelial disorders } \\
\hline Species & $\begin{array}{l}\text { Dose and } \\
\text { route }\end{array}$ & Duration & Pathways & Altered biomarkers & Reference \\
\hline $\begin{array}{l}\text { Wild-type } \\
\text { CD1 mice }\end{array}$ & $\begin{array}{l}\leq 50 \mathrm{mg} / \mathrm{kg} / \\
\text { day (a low } \\
\text { dose) } \\
\text { ethanol dis- } \\
\text { solved-BPA } \\
\text { in drinking } \\
\text { water }\end{array}$ & $\begin{array}{l}4,8, \text { and } \\
16 \text { weeks }\end{array}$ & $\begin{array}{l}\uparrow \text { expression of inflammatory cyto- } \\
\text { kines, TNF-a, RIP-3, caspase-I } \\
\text { activating CAM-KII } \\
\downarrow \text { PARP expression }\end{array}$ & $\begin{array}{l}\uparrow \text { oxidative stress } \\
\downarrow \text { eNOS expression, TBARS } \\
\text { abrogated acetylcholine-induced } \\
\text { vasorelaxation } \\
\uparrow \text { lipid peroxidation, decreased } \\
\text { glutathione }(\mathrm{GSH}) \text { levels }\end{array}$ & $\begin{array}{l}\text { Reventun et } \\
\text { al., } 2020\end{array}$ \\
\hline $\begin{array}{l}\text { Male albino } \\
\text { Wistar rats }\end{array}$ & $\begin{array}{l}35 \mathrm{mg} / \mathrm{kg} / \\
\text { day orally }\end{array}$ & 60 days & $\begin{array}{l}\uparrow \text { vascular cell adhesion molecule } \\
\uparrow \text { lipid peroxidation }\end{array}$ & $\begin{array}{l}\uparrow \text { ROS/RNS, oxidative stress } \\
\downarrow \text { acetylcholine-induced relaxa- } \\
\text { tion }\end{array}$ & $\begin{array}{l}\text { Rameshrad } \\
\text { et al., } 2018\end{array}$ \\
\hline $\begin{array}{l}\text { Male Wistar } \\
\text { rats }\end{array}$ & $\begin{array}{l}0.1 \mathrm{mg} / \mathrm{kg} / \\
\text { day orally }\end{array}$ & 60 days & $\begin{array}{l}\uparrow \text { ROS, NADPH oxidase } \\
\uparrow \text { prostanoids-mediated vasocon- } \\
\text { striction }\end{array}$ & $\begin{array}{l}\downarrow \mathrm{NO} \\
\text { impaired acetylcholine-induced } \\
\text { relaxation }\end{array}$ & $\begin{array}{l}\text { Friques et } \\
\text { al., } 2020\end{array}$ \\
\hline $\begin{array}{l}\text { Wild-type } \\
\text { CD1 mice }\end{array}$ & $\begin{array}{l}4 \mathrm{nM} \text { to } 400 \\
\mu \mathrm{M} \text { in drink- } \\
\text { ing water }\end{array}$ & 30 days & $\begin{array}{l}\uparrow \text { arterial angiotensin II } \\
\uparrow \text { NADPH oxidase }\end{array}$ & $\begin{array}{l}\text { impairment of acetylcholine } \\
\text { relaxation } \\
\text { significant superoxide and per- } \\
\text { oxynitrite accumulation }\end{array}$ & $\begin{array}{l}\text { Saura et al., } \\
2014\end{array}$ \\
\hline
\end{tabular}

hypertensive mice, the expression of SIRT-3 and SIRT-6 is noted to be depleted which elevates SOD2 acetylation, caspase-I, Nf-KB activity, VCAM, ICAM and MCP1 levels that are responsible for ROS/RNS genaration leading to vascular endothelial dysfunction and associated cardiovascular disorders (Dikalova et al., 2020). A novel blood pressure regulator GATA-5 also expressed through SIRT-6 by inhibiting Nkx-3 transcription. Hypertension induced by deoxycorticosterone is also associated with increased systolic blood pressure, decreased NO levels in plasma and increased endoplasmic reticulum stress which elevates GRP78, IP3R1 and EGFR levels (Guo et al., 2019a).

\section{B) Monocrotaline-induced}

Monocrotaline is a macrocyclic pyrazolidine alkaloid obtained from Crotalaria spectabilis associated with proliferative vasculitis, remodelling of pulmonary vessels, endothelial dysfunction and oxidative stress. A single administration $(60 \mathrm{mg} / \mathrm{kg})$ of monocrotaline induces pulmonary vascular syndrome in animal model within 2-3 weeks (Li et al., 2014). Monocrotaline directly contributes to causing pulmonary hypertension by increasing the ROS/RNS generation and accumulation which results in vascular endothelial dysfunction (Steven et al., 2017). Monocrotaline-induced vascular endothelial dysfunction on a single administration via subcutaneous route influences the normal physiology and acts by decreasing the levels of PPAR- $\gamma$, PI3K-Akt, and elevating the levels of inflammatory cytokines, Ang-II and adhesion molecules. These pathways, directly and indirectly, mediates the generation and accumulation of ROS/RNS which tends to decrease acetylcholine-induced vasorelaxation and alters the bioavailability of eNOS leading to the loss of vascular tone, integrity and free flow of the blood ( $\mathrm{Li}$ et al., 2014). Monocrotaline is responsible for apoptosis of the endothelial cells as it decreases the anti-apoptotic factors (Sahara et al., 2012).

\section{C) Ethinyl estradiol-induced}

Ethinyl estradiol is one of the major components found in birth controlling pills but is also associated with the risk of the blood clot which can further lead to cardiovascular disease including stroke, hypertension and high cholesterol, which stimulates endothelial cells to release vasoactive components (Balakumar et al., 2007). The combined pill increases the blood pressure, uric acid, C-reactive proteins, PAI-1 and activates the expression of RAAS (angiotensin converting enzyme, ATR's, Ang-II) as well as increases the level of pro-inflammatory mediators. A study stated that the ethinyl estradiol-treated experimental model reverses the relaxation to acetylcholine. The risk of hypertension in ethinyl estradiol-treated rats is accompanied by endothelial degradations and elevated levels of proinflammatory factors and RAAS (Olatunji et al., 2016). The administration of ethinyl estradiol is also considered as a factor for premature atherosclerosis, thrombogenesis and causes change in the endothelial structure and its function.

\section{D) Spontaneous hypertensive rats}

Spontaneous hypertensive rat is the genetic laboratory hypertensive animal model prepared by inbreeding of Wistar-Kyoto rats with elevated blood pressure. The spontaneous hypertensive rat is characterized by various vascular disorders. Spontaneous hypertensive rat tends to increase the expression of angiotensin and mediates the release of inflammatory factors worsening the integrity of the vascular endothelial altering the 
Table VII

\begin{tabular}{|c|c|c|c|c|c|}
\hline \multicolumn{6}{|c|}{ Deoxycorticosterone-induced vascular endothelial disorders } \\
\hline Species & $\begin{array}{l}\text { Dose and } \\
\text { route }\end{array}$ & Duration & Pathways & Altered biomarkers & Reference \\
\hline $\begin{array}{l}\text { Male Wistar } \\
\text { rats }\end{array}$ & $\begin{array}{l}50 \mathrm{mg} / \mathrm{kg} \text { in } \\
\text { corn oil, sub- } \\
\text { cutaneous }\end{array}$ & $\begin{array}{l}\text { once a } \\
\text { week for } \\
5 \text { weeks }\end{array}$ & $\begin{array}{l}\text { COX and NO blockage } \\
\uparrow \text { prostanoid secretion } \\
\uparrow \text { NADPH oxidase subunit p22 }\end{array}$ & $\begin{array}{l}\uparrow \text { phenylepinephrine-induced } \\
\text { contraction } \\
\downarrow \text { serum/aortic NOS and eNOS }\end{array}$ & $\begin{array}{l}\text { Niazi et al., } \\
2020\end{array}$ \\
\hline $\begin{array}{l}\text { Male Wistar } \\
\text { albino rats }\end{array}$ & $\begin{array}{l}20 \mathrm{mg} / \mathrm{kg} \\
\text { subcutaneous }\end{array}$ & $\begin{array}{l}12 \text { weeks } \\
\text { Twice a } \\
\text { week }\end{array}$ & $\begin{array}{l}\uparrow \mathrm{GRP} 78, \mathrm{IP}_{3} \mathrm{R} 1 \text { and EGFR, } \\
\uparrow \text { expressions of SERCA2 and } \\
\text { Bcl2in vessels }\end{array}$ & $\begin{array}{l}\downarrow \text { serum/aortic NOS and eNOS, } \\
\text { acetyl-induced vasorelaxation }\end{array}$ & $\begin{array}{l}\text { Han et al., } \\
2019\end{array}$ \\
\hline $\begin{array}{l}\text { Male Wistar } \\
\text { rats }\end{array}$ & $\begin{array}{l}20 \mathrm{mg} / \mathrm{kg} \text { in } \\
\text { olive oil, } \\
\text { subcutaneous }\end{array}$ & $\begin{array}{l}\text { twice } \\
\text { weekly } \\
\text { for } 12 \\
\text { weeks. }\end{array}$ & $\begin{array}{l}\uparrow \text { interleukin } 6 \text {, C-reactive protein, } \\
\text { inflammation mediators }\end{array}$ & $\begin{array}{l}\uparrow \text { inflammatory cell infiltration, } \\
\text { fibrosis and arteriosclerotic alter- } \\
\text { ations } \\
\downarrow \text { endothelial integrity, NOS } \\
\text { activity and bioavailability }\end{array}$ & $\begin{array}{l}\text { Kubacka et } \\
\text { al., } 2019\end{array}$ \\
\hline Dog & $\begin{array}{l}\text { day } 1 \text { ( } 20 \mathrm{mg} / \\
\mathrm{kg} \text {, intramus- } \\
\text { cular) day } 14 \\
(10 \mathrm{mg} / \mathrm{kg} \text {, } \\
\text { intramuscu- } \\
\text { lar) }\end{array}$ & $\begin{array}{l}\text { Day } 1 \\
\text { and day } \\
14\end{array}$ & $\begin{array}{l}\text { altered Ang-II, vasopressin activity } \\
\text { tachycardia }\end{array}$ & $\begin{array}{l}\text { failed vasodilatory responses } \\
\uparrow \text { intracellular } \mathrm{Ca}^{+2}\end{array}$ & $\begin{array}{l}\text { Ueno et al., } \\
1988\end{array}$ \\
\hline $\begin{array}{l}\text { Male Wistar } \\
\text { rats }\end{array}$ & $\begin{array}{l}50 \mathrm{mg} / \mathrm{kg} \\
\text { subcutaneous }\end{array}$ & $\begin{array}{l}\text { Twice a } \\
\text { week }\end{array}$ & $\begin{array}{l}\text { altered Ang-II, vasopressin activity } \\
\text { tachycardia }\end{array}$ & $\begin{array}{l}\text { failed vasodilatory responses } \\
\uparrow \text { intracellular } \mathrm{Ca}^{+2}\end{array}$ & $\begin{array}{l}\text { Basso et al., } \\
1985\end{array}$ \\
\hline
\end{tabular}

vascular tone. Spontaneous hypertensive rat is governed by increase ROS/RNS production while it is reported to show altered vasorelaxation towards acetylcholine (Chi et al., 2017).

Taken together, it may be concluded that deoxycorticosterone and monocrotaline are gaining more attention by researchers for the induction of vascular endothelial dysfunction in males. Both models are associated with increased ROS generation and reduction in NO level. However, deoxycorticosterone-induced vascular endothelial dysfunction has been correlated with the slow pathogenetic mechanism as deoxycorticosterone (20 $\mathrm{mg} / \mathrm{kg}$, subcutaneously) administration once weekly took 12 weeks to induce vascular endothelial dysfunction. On another hand, a single intravenous injection of monocrotaline in doses ranging from $(30-60 \mathrm{mg} / \mathrm{kg}$ ) takes 2-6 weeks to induce experimental vascular endothelial dysfunction. Among hypertension-associated vascular endothelial dysfunction models, ethinyl estradiol in combination with norgestrel is considered as the gold standard for evaluation of vasoprotective potential of an agent against vascular endothelial dysfunction in females. For short-term studies, especially where the agent is evaluated for its potential to modulate the RAAS pathway, spontaneous hypertensive rat is preferred (Table VII to IX).

\section{PM-2.5 induced}

Tiny and fine inhalable elements of diameter $<2.5 \mu \mathrm{m}$ present in air is one of the most common and most dangerous air pollutants responsible for causing severe health problems including vascular complications.
Acute and chronic exposure to PM-2.5 for short or long duration through inhalation not only affects lungs but after reaching to blood vessels can cause vascular endothelial dysfunction and can lead to cardiovascular disorders. PM-2.5 increases the vascular permeability and can alter the barrier function of blood vessels. A study demonstrated that PM-2.5 instigates the release of Ang-II, angiotensin converting enzyme and AT-1R in the blood vessels which subsequently increases oxidative stress (ROS/RNS) by enhancing the release of proinflammatory mediators (Qimuge et al., 2019). In addition, PM-2.5 exposed animal model reveals a negative co-relation between eNOS, acetylcholine and TNF-a; as the levels of TNFa in PM-2.5-induced animals are elevated while the acetylcholine-induced vasorelaxation is altered due to the decreased levels of eNOS. It is worthwhile to note that PM-2.5 associated accumulation of adhesion molecule in the blood vessels creates an imbalance between vasoconstricting and vasorelaxing factors (Liang et al., 2019) that further worsen the vascular integrity. Further, PM-2.5 exposure induces the expression of NRF-2, HO-1 that enhances the oxidative stress ultimately, alters the blood vessel integrity. Moreover, eosin and hematoxylin staining of rat aorta revealed that PM-2.5 also increases vascular permeability resulting in interstitial edema and vascular injuries due to the accumulation of inflammatory cells. A decrease in the aortic lumen diameter and an increase in thickness of the endothelial layer is also observed in PM 2.5-treated rat aorta (Dai et al., 2017). Summarized data (Table $X)$ suggest that intratracheal instillation of PM-2.5 from $1.8-16.2 \mathrm{mg} / \mathrm{kg}$ is in practice to induce experimental vascular endothelial dysfunction. Intra- 
Table VIII

Monocrotaline-induced vascular endothelial disorders

\begin{tabular}{|c|c|c|c|c|c|}
\hline Species & Dose and route & Duration & Pathways & Altered biomarkers & Reference \\
\hline $\begin{array}{l}\text { Male Wistar } \\
\text { rats }\end{array}$ & $\begin{array}{l}30,40 \text { and } 60 \\
\mathrm{mg} / \mathrm{kg} \text { single } \\
\text { intravenous }\end{array}$ & $\begin{array}{l}2,4 \text { and } \\
6 \text { weeks }^{\text {th }} \\
\text { i.e. } 14^{\text {th }} \\
28^{\text {th }} \text { and } \\
43^{\text {rd }} \text { day }\end{array}$ & $\begin{array}{l}\uparrow \text { endothelial dysfunction } \\
\uparrow \text { ROS/RNS } \\
\uparrow \text { endothelin- } 1 \text { activity } \\
\uparrow \text { pulmonary wall thickening }\end{array}$ & $\begin{array}{l}\downarrow \text { NO'S }^{\prime} \\
\uparrow \text { uncoupling of eNOS } \\
\uparrow \text { adhesion molecules (ICAMS/ } \\
\text { VCAMS) }\end{array}$ & $\begin{array}{l}\text { Steven et } \\
\text { al., } 2017\end{array}$ \\
\hline $\begin{array}{l}\text { Male Spra- } \\
\text { gue Dawley } \\
\text { rat }\end{array}$ & $\begin{array}{l}60 \mathrm{mg} / \mathrm{kg} \text { single } \\
\text { subcutaneous }\end{array}$ & $\begin{array}{l}\text { single- } \\
\text { dose }\end{array}$ & $\begin{array}{l}\downarrow \text { expression of } \mathrm{PPAR}^{\gamma} \\
\downarrow \text { PI3K-Akt } \\
\downarrow \text { eNOS }\end{array}$ & $\begin{array}{l}\downarrow \text { vasorelaxation } \\
\uparrow \text { vascular remodelling } \\
\uparrow \text { ROS/RNS } \\
\downarrow \text { acetylcholine-induced endothe- } \\
\text { lium-dependent vasorelaxation } \\
\text { of pulmonary arteries }\end{array}$ & $\begin{array}{l}\text { Li et al., } \\
2014\end{array}$ \\
\hline $\begin{array}{l}\text { Sprague- } \\
\text { Dawley rats }\end{array}$ & $60 \mathrm{mg} / \mathrm{kg}$ & & $\begin{array}{l}\uparrow \mathrm{RVSP} \\
\uparrow \text { up-regulation of caspase-III } \\
\downarrow \text { PI3K/Akt } \\
\downarrow \text { anti-apoptotic factors (BCl-2) }\end{array}$ & $\begin{array}{l}\text { Down-regulated eNOS expres- } \\
\text { sion } \\
\uparrow \text { ROS }\end{array}$ & $\begin{array}{l}\text { Sahara et } \\
\text { al., } 2012\end{array}$ \\
\hline
\end{tabular}

Table IX

Ethinyl estradiol-induced vascular endothelial disorders

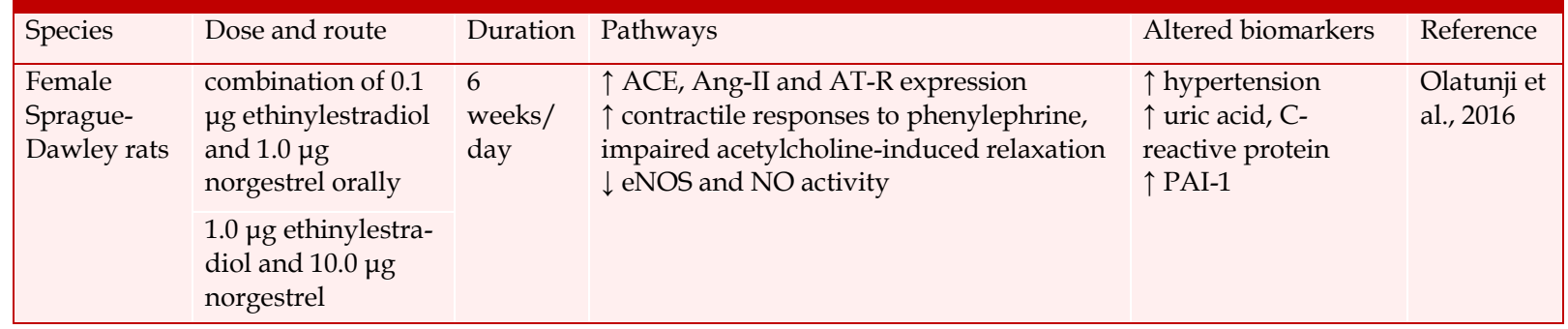

tracheal instillation of PM-2.5 from $5.4 \mathrm{mg} / \mathrm{kg}$ to Sprague-Dawley rat seems to be the most preferable model.

\section{Monosodium glutamate-induced}

Monosodium glutamate (ajinomotto) acts as a neurotransmitter that affects the physiology of the body, leading to various disorders (Niaz et al., 2018). Excessive consumption of ajinomotto is associated with vascular endothelial dysfunction by increasing the oxidative stress along with significant elevation of matrix metaloprotinase-1 and endothelin-1 levels (Abo Zeid et al., 2020). Injurious role of monosodium glutamate is confirmed as triglycerides, total cholesterol, LDL-C, TNF-a are found to be increased while NO levels are decreased in serum and aorta tissue homogenate. Decreased expression of Akt, $\mathrm{PI} 3 \mathrm{~K}$, and $\mathrm{PGI}_{2}$ are also found to be the governing factors of vascular endothelial dysfunction (Leao et al., 2019). Excessive consumption of monosodium glutamate is reported to increase the ROS generation building the stress on vascular endothelial by inducing the release of inflammatory cytokines that finally resulting in induction and progression of vascular endothelial dysfunction (Lobato et al., 2011). Monosodium glutamate-treated rat aortic endothelium showed the thickening of tunica media along with deposition of fats that reduces the lumen of the aorta. In addition, increased inflammatory mediators are also observed (Abo Zeid et al., 2020). Complied data from different studies in Table XI reflect no variation in dose of monosodium glutamate to induce vascular endothelial dysfunction irrespective of age of the animals. All the models showed common pathogenetic pathways for vascular endothelial dysfunction induction and progression.

\section{Uric acid-induced}

Excessive level of uric acid to severe disorders like gout, diabetes, kidney stones, etc (Fathallah-Shaykh et al., 2013) along with vascular endothelial dysfunction, which is one of the most serious condition which can lead to different cardiovascular disorders. Hyperuricemia is often associated with increased oxidative stress, lipid peroxidation and decreased levels of SOD, nitric oxides, glutathione, thus play a crucial role in induction and progression of vascular endothelial dysfunction. In addition, uric acid-treated animal model reveals that hyperuricemia is also associate with elevation of increased inflammatory mediators, chemokines, 
cytokines and adhesion molecules like VCAM (Oyabambi et al., 2020). Further, the expression of various pathways like Nf-Kb, TNF-a enhanced due to accumulation of uric acid. Moreover, uric acid exposure also activates the RAAS system which increases the expression of Ang-II, angiotensin converting enzyme and angiotensin II receptor type 1 which contributes in causing vascular endothelial dysfunction (Balakumar et al., 2008c). Animal species, dose \& route, duration along with the associated pathways have been summarized in Table XII.

\section{Homocysteine-induced}

Excessive levels of homocysteine, an independent risk factor, contributing to cause vascular endothelial dysfunction and is also associated with cardiovascular system disorders (Moretti and Caruso, 2019; Esse et al., 2019). Homocysteine quenches the level of NO by reducing the bioavailability and uncoupling NOS from its co-factors (Kumar et al., 2017; Ji et al., 2021). Homocysteine-induced vascular endothelial disorder is associated with increased oxidative stress which further instigates the release of pro-inflammatory, apoptotic and pro-thrombotic factors while down-regulates
VEGF, p-tyr-VEGFR2 and phospho-focal adhesion kinase (Tyr397) (Lan et al., 2011; Wang et al., 2019). In addition, phenylepinephrine-induced vasoconstriction and vWf is also noted to be increased. Hyperhomocysteinemia also tends to increase the expression of Ero-1 (endoplasmic reticullum oxidoreductin) which tends to trigger oxidative stress by mediating the generation of ROS/RNS. Homocysteine increases apoptosis by enhancing the release of caspase- 3 and Bax (Ren et al., 2016). Animal species, dose \& route, duration along with the associated pathways have been summarized in Table XIII.

\section{High fat diet-induced}

Obesity is a widespread metabolic disorder which serves as a risk factor for complicating various microand macro-vascular diseases. Different studies stated that consumption of high fat diet is associated with altered NO's function as a result leading to vascular endothelial dysfunction. It is considered as the major cause of morbidity and mortality (Zhao et al., 2020). Increased level of LDL's and v-LDLs in the blood vessels leads to the formation of atherosclerotic

Table X

PM 2.5-induced vascular endothelial disorders

\begin{tabular}{|c|c|c|c|c|c|}
\hline Species & $\begin{array}{l}\text { Dose and } \\
\text { route }\end{array}$ & Duration & Pathways & Altered biomarkers & Reference \\
\hline $\begin{array}{l}\text { Sprague- } \\
\text { Dawley rats }\end{array}$ & $\begin{array}{l}1.8,5.4 \text { and } \\
16.2 \mathrm{mg} / \mathrm{kg} \\
\text { intratracheal } \\
\text { instillation }\end{array}$ & $\begin{array}{l}\text { every } 3 \\
\text { days for } 30 \\
\text { days }\end{array}$ & $\begin{array}{l}\uparrow \text { expression of JAK/STAT signalling } \\
\text { pathway } \\
\uparrow \text { expression of TLR4/p38/NF-kB } \\
\text { pathway } \\
\uparrow \text { arterial thrombus formation }\end{array}$ & $\begin{array}{l}\uparrow \text { inflammatory mediators } \\
\text { (IL-6, VCAM, ICAM, MCP, } \\
\text { CRP) } \\
\text { disruptive fibrinolysis }\end{array}$ & $\begin{array}{l}\text { Liang et al., } \\
2019\end{array}$ \\
\hline $\begin{array}{l}\text { Sprague- } \\
\text { Dawley rats }\end{array}$ & & $\begin{array}{l}\text { once every } \\
3 \text { days for } \\
28 \text { days }\end{array}$ & $\begin{array}{l}\uparrow \text { phosphorylation of STAT3 } \\
\text { up-regulation of miR-21 } \\
\text { inhibits TIMP3/MMP9 signalling }\end{array}$ & $\begin{array}{l}\text { alteration in the barrier func- } \\
\text { tion of the vascular endothe- } \\
\text { lium }\end{array}$ & $\begin{array}{l}\text { Dai et al., } \\
2017\end{array}$ \\
\hline
\end{tabular}

Table XI

Monosodium glutamate-induced vascular endothelial disorders

\begin{tabular}{|c|c|c|c|c|c|}
\hline Species & $\begin{array}{l}\text { Dose and } \\
\text { route }\end{array}$ & Duration & Pathways & Altered biomarkers & Reference \\
\hline $\begin{array}{l}\text { New born } \\
\text { Wister Albi- } \\
\text { no rats }\end{array}$ & $4 \mathrm{mg} / \mathrm{g}$ orally & 14 days & $\begin{array}{l}\uparrow \text { expression of endothelin-1 } \\
\uparrow \text { expression of MMP-1 } \\
\uparrow \text { ROS/RNS } \\
\uparrow \text { NADPH oxidase } \\
\uparrow \text { NOX-4 expression }\end{array}$ & $\begin{array}{l}\downarrow \text { eNOS and NO activity } \\
\uparrow \text { inflammatory response } \\
\uparrow \text { VSMC }\end{array}$ & $\begin{array}{l}\text { Abo Zeid et } \\
\text { al., } 2020\end{array}$ \\
\hline $\begin{array}{l}\text { New born } \\
\text { Wistar rats }\end{array}$ & $\begin{array}{l}4.0 \mathrm{~g} / \mathrm{kg} \text { sub- } \\
\text { cutaneous } \\
\text { injection }\end{array}$ & $\begin{array}{l}\text { second to } \\
\text { the sixth } \\
\text { day after } \\
\text { birth }\end{array}$ & $\begin{array}{l}\uparrow \text { levels of LDL's, vLDL's and triglycerides } \\
\uparrow \text { ROS/RNS } \\
\uparrow \text { phenylepinephrine-induced vasocon- } \\
\text { striction }\end{array}$ & $\begin{array}{l}\downarrow \text { eNOS levels } \\
\text { loss integrity of vascular } \\
\text { endothelium }\end{array}$ & $\begin{array}{l}\text { Lobato et } \\
\text { al., } 2011\end{array}$ \\
\hline $\begin{array}{l}\text { Male Wistar } \\
\text { rats }\end{array}$ & $\begin{array}{l}4.0 \mathrm{~g} / \mathrm{kg} \text { sub- } \\
\text { cutaneous } \\
\text { injection }\end{array}$ & $\begin{array}{l}\text { first } 5 \\
\text { days }\end{array}$ & $\begin{array}{l}\downarrow \text { Akt/ PI-3K expression } \\
\uparrow \text { ROS/RNS } \\
\uparrow \text { cholesterol } \\
\uparrow \text { thrombosis, endothelin- } 1 \\
\uparrow \text { platelet adhesion and aggregation }\end{array}$ & $\begin{array}{l}\downarrow \text { acetylcholine-induced } \\
\text { vasorelaxation } \\
\downarrow \text { expression of } \mathrm{PGI}_{2}, \mathrm{NO}\end{array}$ & $\begin{array}{l}\text { Leao et al., } \\
2019\end{array}$ \\
\hline
\end{tabular}


Table XII

Uric acid-induced vascular endothelial disorders

\begin{tabular}{|c|c|c|c|c|c|}
\hline Species & $\begin{array}{l}\text { Dose and } \\
\text { route }\end{array}$ & Duration & Pathways & Altered biomarkers & Reference \\
\hline $\begin{array}{l}\text { Male } \\
\text { Wistar } \\
\text { rats }\end{array}$ & $\begin{array}{l}150 \mathrm{mg} / \mathrm{kg} / \\
\text { day intraperi- } \\
\text { tonially }\end{array}$ & 3 weeks & $\begin{array}{l}\uparrow \text { generation of ROS/RNS } \\
\downarrow \text { acetylcholine-induced endothelium- } \\
\text { dependent relaxation } \\
\uparrow \text { activation of NADPH oxidase } \\
\uparrow \text { xanthine oxidase } \\
\text { up-regulate the expression of various } \\
\text { fibroblast growth factor, tumor necro- } \\
\text { sis factor and plasminogen activator } \\
\text { inhibitor- } 1 \\
\uparrow \text { mononuclear leukocyte adhesion } \\
\uparrow \text { expression of adhesion molecules } \\
\text { such as VCAM-1 and ICAM }\end{array}$ & $\begin{array}{l}\downarrow \text { aortic and serum nitrite/nitrate, } \\
\uparrow \text { aortic superoxide anion genera- } \\
\text { tion, } \\
\downarrow \text { acetylcholine-induced endotheli- } \\
\text { um-dependent relaxation } \\
\text { impairing endothelial integrity, } \\
\text { inducing vascular oxidative stress } \\
\uparrow \text { serum TBARS } \\
\text { down-regulating the expression of } \\
\text { eNOS } \\
\text { impairing endothelial integrity }\end{array}$ & $\begin{array}{l}\text { Balakumar } \\
\text { et al., } \\
\text { 2008c; }\end{array}$ \\
\hline $\begin{array}{l}\text { Female } \\
\text { Wistar } \\
\text { rats }\end{array}$ & $\begin{array}{l}\text { High salt feed } \\
\text { consisting of } \\
8 \% \mathrm{NaCl}- \\
\text { plasma uric } \\
\text { acid level rise } \\
\text { to } 15 \mathrm{U} / \mathrm{mL}\end{array}$ & 6 weeks & $\begin{array}{l}\uparrow \text { expression of adhesion molecules } \\
\text { such as VCAM- } 1 \text { and ICAM }\end{array}$ & $\begin{array}{l}\downarrow \text { aortic and serum nitrite/ nitrate, } \\
\uparrow \text { aortic superoxide anion genera- } \\
\text { tion }\end{array}$ & $\begin{array}{l}\text { Oyabambi } \\
\text { et al., } 2020\end{array}$ \\
\hline
\end{tabular}

plaques which interfere with the free flow of blood. High concentration of fat is responsible for stimulating the vascular endothelial cells to release vasoactive substances, thrombotic factors and decreases vasodilatory substances $\left(\mathrm{NO}, \mathrm{PGI}_{2}\right)$. High cholesterol increases the lipid peroxidation of LDL, which tends to increase the oxidative stress by generating large amounts of ROS/RNS, alters the expression of PI3K-Akt, eNOS and SIRT pathways which leads to the loss of vascular tone, integrity, arginase activity (Huang et al., 2018). Male CDH5 CreERT2 Ftoflox/flox mice fed on $60 \%$ high fat diet for the duration of 8 weeks showed obesity with increased level of cholesterol which directly and indirectly lead to increase the oxidation of LDL's or vLDL's which gets accumulated in the blood vessels resulting in the formation of atherosclerotic plaques and narrowing the lumen of the blood vessels (Kruger et al., 2020). Apart from the mice or rats, male hybrid flanders rabbits is employed to induce obesity and subsequent vascular endothelial dysfunction with standard rabbit chow added with $18 \%$ of fats $(10 \%$ corn oil $+8 \%$ lard) for 6 weeks (Alarcon et al., 2018) . Numerous studies used different percentage of fat to induce obesity with different composition, suggesting that there is huge scope to formulate their high fat diet to induce obesity related vascular endothelial dysfunction.

\section{Glucocorticoid-induced}

Glucocorticoid (play crucial role on metabolism and glucocorticoid analogues like prednisolone, dexamethasone) is also widely employed for reducing the inflammation, fight certain cancers, autoimmune disorders but due to their severe effects on vasculature the use is limited (Yang and Zhang, 2004). Excessive levels of glucocorticoids are associated with vasoconstriction, altered capillary permeability, Atherosclerosis and increased blood pressure i.e. hypertension which overall results in vascular endothelial dysfunction (Ross and Linch, 1982). Glucocorticoids has been noted to increase the superoxide levels which led to the uncoupling of eNOS from its co-factors resulting in NO's dysfunctioning (Akaike and Matsumoto, 2007). In addition, mice treated with dexamethasone (0.1-3 $\mathrm{mg} / \mathrm{kg}$ ) revealed that glucocorticoid involves downregulation of eNOS, down-regulation of cationic amino acid transporter-1, and 3) and generation of reactive oxygen species for induction of vascular abrasion (Schafer et al., 2005). It is worthwhile to note that endothelium-dependent vasodilation in response to acetylcholine $(0.1-10 \mu \mathrm{M})$ is reduced by dexamethasone in a dose-dependent fashion (Schafer et al., 2005).

\section{Hypochlorite-induced}

Hypochlorite is chlorine ox-anion widely explored for it disinfectant and exposure to hypochlorite can cause skin or eye irritation, severe injuries, burns etc. Hypochlorite itself is a superoxide mediator which is responsible for inducing oxidative stress (Radovits et al., 2013). This generated oxidative stress is responsible for uncoupling the eNOS from its co-factors altering the NO's bioavailability. A study also stated that hypochlorite intensifies the NADPH oxidase activity leading to overproduction of ROS/RNS molecules which creates an imbalance between antioxidant and free radicle resulting in vascular endothelial dysfunction (Tian et al., 2017). Pre-treatment with hypochlorite results in impaired endothelial-dependent vasorelaxation and acetylcholine-induced vasorelaxation and increases the formation of atherosclerotic plaques 
Table XIII

Homocysteine-induced vascular endothelial disorders

\begin{tabular}{|c|c|c|c|c|c|}
\hline Species & Dose and route & Duration & Pathways & Altered biomarkers & Reference \\
\hline $\begin{array}{l}\text { Male Sprague } \\
\text { Dawley rats }\end{array}$ & $\begin{array}{l}3 \% \text { methionine } \\
(\mathrm{w} / \mathrm{w}) \text { in feed }\end{array}$ & 8 weeks & $\begin{array}{l}\uparrow \text { endothelin-1, Ang-II } \\
\uparrow \text { TXA-2 } \\
\downarrow \text { PGI-2 } \\
\uparrow \text { expression of RAAS }\end{array}$ & $\begin{array}{l}\text { rapid decomposition of } \mathrm{NO} \\
\uparrow \text { thrombosis } \\
\text { inhibition of NO production and } \\
\text { eNOS }\end{array}$ & $\begin{array}{l}\text { Ji et al., } \\
2020\end{array}$ \\
\hline $\begin{array}{l}\text { Male Wistar } \\
\text { rats }\end{array}$ & $\begin{array}{l}\text { L-methionine } \\
1.7 \mathrm{~g} / \mathrm{kg} / \text { day, } \\
\text { orally }\end{array}$ & 32 days & $\begin{array}{l}\uparrow \text { phenylepinephrine-induced } \\
\text { constriction } \\
\uparrow \text { ROS/ RNS } \\
\downarrow \text { NO bioavailability } \\
\downarrow \text { SOD, GSH. CAT }\end{array}$ & $\begin{array}{l}\text { attenuated vasorelaxation } \\
\text { impaired eNOS activity } \\
\uparrow \text { TBARS }\end{array}$ & $\begin{array}{l}\text { Kumar et } \\
\text { al., } 2017\end{array}$ \\
\hline $\begin{array}{l}\text { Male Sprague- } \\
\text { Dawley rats }\end{array}$ & $\begin{array}{l}\text { L-methionine } 1 \\
\mathrm{~g} / \mathrm{kg} / \text { day } \\
\text { intragastricly }\end{array}$ & 4 weeks & $\begin{array}{l}\downarrow \text { PI3K, Akt } \\
\uparrow \text { oxidative stress } \\
\downarrow \text { NO bioavailability }\end{array}$ & $\begin{array}{l}\text { down-regulating the expression of } \\
\text { eNOS } \\
\text { impairing endothelial integrity }\end{array}$ & $\begin{array}{l}\text { Lan et al., } \\
2011\end{array}$ \\
\hline $\begin{array}{l}\text { Male Sprague- } \\
\text { Dawley rats }\end{array}$ & $\begin{array}{l}\text { L-methionine } \\
\text { by } 1 \mathrm{~g} / \mathrm{kg} / \\
\text { day intra- } \\
\text { gastricly }\end{array}$ & 4 weeks & $\begin{array}{l}\uparrow \text { apoptotic factors, and apopto- } \\
\text { sis of endothelial cells } \\
\uparrow \text { caspase- } 3 \text {, bax } \\
\downarrow \text { Akt expression }\end{array}$ & $\begin{array}{l}\uparrow \text { vascular injury } \\
\text { impaired endothelium-derived } \\
\text { vasorelaxation } \\
\downarrow \text { eNOS activity } \\
\downarrow \text { NO bioavailability }\end{array}$ & $\begin{array}{l}\text { Ren et al., } \\
2016\end{array}$ \\
\hline
\end{tabular}

(Ding et al., 2014). Isolated aorta of rat exposed to hypochlorite at the dose of $100-400 \mu \mathrm{M}$ is found to be associated with decreased acetylcholine-induced vasorelaxation. This alteration in vascular tone is due to eNOS uncoupling and decreased the NO bioavailability (Tian et al., 2017). In addition, the exposed aorta is found to associated with decreased PARP expression, increased lipid peroxidation, release of inflammatory mediators and increased DNA damage resulting in worsening of vascular endothelial dysfunction (Radovits et al., 2013).

\section{Endotoxin-induced}

Lipopolysaccharide is one of the most common endotoxins formed by covalent bond between lipid A and polysaccharide. It is found in the outer layer of the Gram negative bacteria (Lynn and Golenbock, 1992). Endotoxins stimulate the endothelial cells to activate fibroblasts (Echeverría et al., 2014) and enhance the release of pro-inflammatory cytokines, and increase oxidative stress burst which result in causing fever, inflammation, aseptic shock and death. Lipo-polysaccharide ( $1 \mathrm{mg} / \mathrm{kg}$ intraperitoneal once) to mice is noted to be associated with increased mRNA levels of IL-6, and IL-8 (Huang et al., 2019). While single intravenous administration of E. coli $15 \mathrm{mg} / \mathrm{kg}$ established vascular endothelial dysfunction in rats within 6 hours (Balakumar et al., 2007). Activation of fibroblast leads to endothelial fibrosis which tends to alter the NO's bioavailability leading to vascular endothelial dysfunction especially pulmonary vascular injury (Chuaiphichai et al., 2016; Huang et al., 2019).

\section{Overectomy/estrogen deficiency-induced}

Oestrogen, an endocrine hormone has been noted to regulate eNOS activity which helps to release sufficient amount of $\mathrm{NO}$ for the vasodilation of the vessel. Low levels of oestrogen in post-menopausal female is one of the causes for increased risk of cardiovascular disease. Low levels of oestrogen up-regulates RAAS system which results in hypertension and is also responsible for atherosclerotic plaque formation while it also increases the concentration of free radicles which activates endothelial cells to cause vascular endothelial dysfunction (Wassmann et al., 2001). Thus, to establish the correlation between the hypertension, oestrogen deficiency associated vascular endothelial dysfunction, overiectomized spontaneously hypertensive female rats are considered to be gold standard and are widely used to evaluate the therapeutic agents for their potential to manage the vascular complications in menopausal condition.

\section{Conclusion}

To understand complex pathogenesis and to develop a new therapeutic alternative for treating vascular endothelial dysfunction animal models are widely used. Continued utilization of these experimental models simulating human vascular endothelial dysfunction, particularly those that combine other clinically relevant comorbidities like obesity, nicotine intake, hyperuricemia or hypercholesterolemia, may open a new vista in development of effective strategies to address the vascular complications. Nevertheless, a restrained methodology is mandatory while experimental findings in these models are extrapolated to human vascular endothelial dysfunction. 


\section{Financial Support}

Self-funded

\section{Conflict of Interest}

Authors declare no conflict of interest

\section{References}

Abo Zeid AA, Rowida Raafat I, Ahmed AG. Berberine alleviates monosodium glutamate induced postnatal metabolic disorders associated vascular endothelial dysfunction in newborn rats: Possible role of matrix metalloproteinase1. Arch Physiol Biochem. 2020; 19: 1-12.

Adel H, Taye A, Khalifa MM. Spironolactone improves endothelial dysfunction in streptozotocin-induced diabetic rats. Naunyn Schmiedebergs Arch Pharmacol. 2014; 387: 1187-97.

Akaike M, Matsumoto T. Glucocorticoid-induced reduction in NO bioavailability and vascular endothelial dysfunction. Clin Calcium. 2007; 17: 864-70.

Alarcon G, Roco J, Medina M, Medina A, Peral M, Jerez S. High fat diet-induced metabolically obese and normal weight rabbit model shows early vascular dysfunction: Mechanisms involved. Int J Obes (Lond). 2018; 42: 1535-43.

Azemi AK, Mokhtar SS, Rasool AHG. Clinacanthus nutans leaves extract reverts endothelial dysfunction in type 2 diabetes rats by improving protein expression of eNOS. Oxid Med Cell Longev. 2020; 2020.

Babacanoglu C, Yildirim N, Sadi G, Pektas MB, Akar F. Resveratrol prevents high-fructose corn syrup-induced vascular insulin resistance and dysfunction in rats. Food Chem Toxicol. 2013; 60: 160-67.

Baig MA, Panchal SS. Streptozotocin-induced diabetes mellitus in neonatal rats: An insight into its applications to induce diabetic complications. Curr Diabetes Rev. 2019; 16: 26-39.

Balakumar P, Chakkarwar VA, Kumar V, Jain A, Reddy J, Singh M. Experimental models for nephropathy. J Renin Angiotensin Aldosterone Syst. 2008a; 9: 189-95.

Balakumar P, Chakkarwar VA, Singh M. Ameliorative effect of combination of benfotiamine and fenofibrate in diabetesinduced vascular endothelial dysfunction and nephropathy in the rat. Mol Cell Biochem. 2009; 320: 149-62.

Balakumar P, Jindal S, Shah DI, Singh M. Experimental models for vascular endothelial dysfunction. Trends Med Res. 2007; 2: 12-20.

Balakumar P, Kaur T, Singh M. Potential target sites to modulate vascular endothelial dysfunction: Current perspectives and future directions. Toxicology 2008b; 245: 4964.

Balakumar P, Sharma R, Singh M. Benfotiamine attenuates nicotine and uric acid-induced vascular endothelial dysfunction in the rat. Pharmacol Res. 2008c; 58: 356-63.
Basso N, Ruiz P, Kurnjek ML, Cannata MA, Taquini AC. The brain renin-angiotensin system and the development of DOC-salt hypertension. Clin Exp Hypertension. 1985; A7: 1259-68.

Brahmanaidu P, Uddandrao VVS, Sasikumar V, Naik RR, Pothani S, Begum MS, Rajeshkumar MP, Varatharaju C, Meriga B, Rameshreddy P, Kalaivani A, Saravanan G. Reversal of endothelial dysfunction in aorta of streptozotocin-nicotinamide-induced type- 2 diabetic rats by Sallylcysteine. Mol Cell Biochem. 2017; 432: 25-32.

Capellini VK, Baldo CF, Celotto AC, Batalhão ME, Cárnio EC, Rodrigues AJ, Evora PR. Oxidative stress is not associated with vascular dysfunction in a model of alloxan-induced diabetic rats. Arq Bras Endocrinol Metabol. 2010; 54: 53039 .

Carvalho C, Santos RX, Cardoso S, Correia S, Oliveira PJ, Santos MS, Moreira PI. Doxorubicin: The good, the bad and the ugly effect. Curr Med Chem. 2009; 16: 3267-85.

Chakkarwar VA. Fenofibrate attenuates nicotine-induced vascular endothelial dysfunction in the rat. Vascul Pharmacol. 2011; 55: 163-68.

Chi L, Hu X, Zhang W, Bai T, Zhang L, Zeng H, Guo R, Zhang Y, Tian H. Adipokine CTRP6 improves PPARY activation to alleviate angiotensin II-induced hypertension and vascular endothelial dysfunction in spontaneously hypertensive rats. Biochem Biophys Res Commun. 2017; 482: 727-34

Chuaiphichai S, Starr A, Nandi M, Channon KM, McNeill E. Endothelial cell tetrahydrobiopterin deficiency attenuates LPS-induced vascular dysfunction and hypotension. Vascul Pharmacol. 2016; 77: 69-79.

Clayton ZS, Brunt VE, Hutton DA, VanDongen NS, D'Alessandro A, Reisz JA, Ziemba BP, Seals DR. Doxorubicin-induced oxidative stress and endothelial dysfunction in conduit arteries is prevented by mitochondrialspecific antioxidant treatment. JACC Cardio Oncol. 2020; 2: $475-88$.

Dai J, Chen W, Lin Y, Wang S, Guo X, Zhang QQ. Exposure to concentrated ambient fine particulate matter induces vascular endothelial dysfunction via miR-21. Int J Biol Sci. 2017; 13: 868-77.

Dikalova AE, Pandey A, Xiao L, Arslanbaeva L, Sidorova T, Lopez MG, Billings FT 4th, Verdin E, Auwerx J, Harrison DG, Dikalov SI. Mitochondrial deacetylase Sirt3 reduces vascular dysfunction and hypertension while Sirt3 depletion in essential hypertension is linked to vascular inflammation and oxidative stress. Circ Res. 2020; 126: 439-52.

Ding Y, Zhang B, Zhou K, Chen M, Wang M, Jia Y, Song Y, Li Y, Wen A. Dietary ellagic acid improves oxidant-induced endothelial dysfunction and atherosclerosis: Role of Nrf2 activation. Int J Cardiol. 2014; 175: 508-14.

Echeverría C, Montorfano I, Tapia P, Riedel C, CabelloVerrugio C, Simon F. Endotoxin-induced endothelial fibrosis is dependent on expression of transforming growth factors $\beta 1$ and $\beta 2$. Infect Immun. 2014; 82: 3678-86.

El-Bassossy HM, Dsokey N, Fahmy A. Characterization of vascular complications in experimental model of fructose- 
induced metabolic syndrome. Toxicol Mech Methods. 2014; 24: $536-43$.

Ellinsworth DC. Arsenic, reactive oxygen, and endothelial dysfunction. J Pharmacol Exp Ther. 2015; 353: 458-64.

Esse R, Barroso M, Tavares de Almeida I, Castro R. The contribution of homocysteine metabolism disruption to endothelial dysfunction: State-of-the-art. Int J Mol Sci. 2019; 20: 867.

Fadini GP, Avogaro A. Cell-based methods for ex vivo evaluation of human endothelial biology. Cardiovasc Res. 2010; 87: 12-21.

Fathallah-Shaykh SA, Cramer MT. Uric acid and the kidney. Pediatr Nephrol. 2014; 29: 999-1008.

Friques AGF, Santos FDN, Angeli DB, Silva FAC, Dias AT, Aires R, Leal MAS, Nogueira BV, Amorim FG, Campagnaro BP, Pereira TMC, Campos-Toimil M, Meyrelles SS, Vasquez EC. Bisphenol A contamination in infant rats: Molecular, structural, and physiological cardiovascular changes and the protective role of kefir. J Nutr Biochem. 2020; 75 : 108254

Guo J, Wang Z, Wu J, Liu M, Li M, Sun Y, Huang W, Li Y, Zhang Y, Tang W, Li X, Zhang C, Hong F, Li N, Nie J, Yi F. Endothelial SIRT6 is vital to prevent hypertension and associated cardiorenal injury through targeting Nkx3.2GATA5 signalling. Circ Res. 2019a; 124: 1448-61.

Guo X, Fu X, Liu X, Wang J, Li Z, Gao L, Li Y, Zhang W. Role of pigment epithelium-derived factor in arsenic-induced vascular endothelial dysfunction in a rat model. Biol Trace Elem Res. 2019b; 190: 405-13.

Guo X, Liu X, Wang J, Fu X, Yao J, Zhang X, Jackson S, Li J, Zhang W, Sun D. Pigment epithelium-derived factor (PEDF) ameliorates arsenic-induced vascular endothelial dysfunction in rats and toxicity in endothelial EA. hy926 cells. Environ Res. 2020; 186: 109506.

Hadi HA, Carr CS, Al Suwaidi J. Endothelial dysfunction: Cardiovascular risk factors, therapy, and outcome. Vasc Health Risk Manag. 2005; 1: 183-98.

Han S, Bal NB, Sadi G, Usanmaz SE, Tuglu MM, Uludag MO, Demirel-Yilmaz E. Inhibition of endoplasmic reticulum stress protected DOCA-salt hypertension-induced vascular dysfunction. Vascul Pharmacol. 2019; 113: 38-46.

Huang JP, Hsu SC, Li DE, Chen KH, Kuo CY, Hung LM Resveratrol mitigates high-fat diet-induced vascular dysfunction by activating the Akt/eNOS/NO and Sirt1/ER pathway. J Cardiovasc Pharmacol. 2018; 72: 231-41.

Huang X, Zhu J, Jiang Y, Xu C, Lv Q, Yu D, Shi K, Ruan Z, Wang Y. SU5416 attenuated lipopolysaccharide-induced acute lung injury in mice by modulating properties of vascular endothelial cells. Drug Des Devel Ther. 2019; 13: 1763 72.

Ji B, Yuan K, Li J, Ku BJ, Leung PS, He W. Protocatechualdehyde restores endothelial dysfunction in streptozotocin-induced diabetic rats. Ann Transl Med. 2021a; 9: 711.

Ji XW, Lyu HJ, Zhou GH, Wu B, Zhu YY, Wu TH, Zhang F, Jin SN, Cho KW, Wen JF. Physcion, a tetra-substituted 9,10anthraquinone, prevents homocysteine-induced endothelial dysfunction by activating Ca2+- and Akt-eNOS-NO signaling pathways. Phytomedicine 2021b; 81: 153410.

Jyoti U, Kansal SK, Kumar P, Goyal S. Possible vasculoprotective role of linagliptin against sodium arsenite-induced vascular endothelial dysfunction. Naunyn Schmiedebergs Arch Pharmacol. 2016; 389: 167-75.

Kaur T, Goel RK, Balakumar P. Effect of rosiglitazone in sodium arsenite-induced experimental vascular endothelial dysfunction. Arch Pharm Res. 2010; 33: 611-18.

Kesavan M, Sarath TS, Kannan K, Suresh S, Gupta P, Vijayakaran K, Sankar P, Kurade NP, Mishra SK, Sarkar $\mathrm{SN}$. Atorvastatin restores arsenic-induced vascular dysfunction in rats: Modulation of nitric oxide signaling and inflammatory mediators. Toxicol Appl Pharmacol. 2014; 280: $107-16$

Khitan Z, Kim DH. Fructose: A key factor in the development of metabolic syndrome and hypertension. J Nutr Metab. 2013; 2013

Kho MC, Lee YJ, Cha JD, Choi KM, Kang DG, Lee HS Gastrodia elata ameliorates high-fructose diet-induced lipid metabolism and endothelial dysfunction. Evid Based Complement Alternat Med. 2014; 2014.

Kruger N, Biwer LA, Good ME, Ruddiman CA, Wolpe AG, DeLalio LJ, Murphy S, Macal EH Jr, Ragolia L, Serbulea V, Best AK, Leitinger N, Harris TE, Sonkusare SK, Gödecke A, Isakson BE. Loss of endothelial FTO antagonizes obesityinduced metabolic and vascular dysfunction. Circ Res. 2020; 126: 232-42.

Kshirsagar RP, Chouthe RS, Reddy GB, Bhardwaj DK, Diwan PV. Geraniol ameliorates endothelial dysfunction in streptozotocin-induced diabetic rats. J Pharm Res. 2017; 11: 1159 -65 .

Kubacka M, Zadrożna M, Nowak B, Kotańska M, Filipek B, Waszkielewicz AM, Marona H, Mogilski S. Reversal of cardiac, vascular, and renal dysfunction by non-quinazoline a1-adrenolytics in DOCA-salt hypertensive rats: A comparison with prazosin, a quinazoline-based a1-adrenoceptor antagonist. Hypertens Res. 2019; 42: 1125-41.

Kumar BH, Reddy AR, Kumar JM, Bhardwaj DK, Diwan PV. Effects of fisetin on hyperhomocysteinemia-induced experimental endothelial dysfunction and vascular dementia. Can J Physiol Pharmacol. 2017; 95: 32-42.

Lan TH, Xu ZW, Wang Z, Wu YL, Wu WK, Tan HM. Ginsenoside Rb1 prevents homocysteine-induced endothelial dysfunction via PI3K/Akt activation and PKC inhibition. Biochem Pharmacol. 2011; 82: 148-55.

Le Brocq M, Leslie SJ, Milliken P, Megson IL. Endothelial dysfunction: From molecular mechanisms to measurement, clinical implications, and therapeutic opportunities. Antioxid Redox Signal. 2008; 10: 1631-74.

Leao VF, Ferreira LLDM, Melo CM, Bonfleur ML, da Silva LL, Carneiro EM, Raimundo JM, Ribeiro RA. Taurine supplementation prevents endothelial dysfunction and attenuates structural changes in aortas from hypothalamic obese rats. Eur J Nutr. 2019; 58: 551-63.

Li H, Lu W, Cai WW, Wang PJ, Zhang N, Yu CP, Wang DL, Liu BC, Sun W. Telmisartan attenuates monocrotalineinduced pulmonary artery endothelial dysfunction 
through a PPAR gamma-dependent PI3K/Akt/eNOS pathway. Pulm Pharmacol Ther. 2014; 28: 17-24.

Li X, Gu J, Zhang Y, Feng S, Huang X, Jiang Y, Xia Y, Liu Y, Yang $X$. l-arginine alleviates doxorubicin-induced endothelium-dependent dysfunction by promoting nitric oxide generation and inhibiting apoptosis. Toxicology 2019; 423: 105-11.

Liang S, Zhao T, Hu H, Shi Y, Xu Q, Miller MR, Duan J, Sun $Z$. Repeat dose exposure of PM2.5 triggers the disseminated intravascular coagulation (DIC) in SD rats. Sci Total Environ. 2019; 663: 245-53.

Liu C, Zhou MS, Li Y, Wang A, Chadipiralla K, Tian R, Raij L. Oral nicotine aggravates endothelial dysfunction and vascular inflammation in diet-induced obese rats: Role of macrophage TNFa. PLoS One. 2017; 12: e0188439.

Liu Y, Cole V, Lawandy I, Ehsan A, Sellke FW, Feng J. Decreased coronary arteriolar response to KCa channel opener after cardioplegic arrest in diabetic patients. Mol Cell Biochem. 2018; 445: 187-94.

Lobato NS, Filgueira FP, Akamine EH, Davel AP, Rossoni LV, Tostes RC, Carvalho MH, Fortes ZB. Obesity induced by neonatal treatment with monosodium glutamate impairs microvascular reactivity in adult rats: Role of $\mathrm{NO}$ and prostanoids. Nutr Metab Cardiovasc Dis. 2011; 21: 808-16.

Lynn WA, Golenbock DT. Lipopolysaccharide antagonists. Immunol Today. 1992; 13: 271-76.

Malakul W, Pengnet S, Kumchoom C, Tunsophon S. Naringin ameliorates endothelial dysfunction in fructose-fed rats. Exp Ther Med. 2018; 15: 3140-46.

Moretti R, Caruso P. The controversial role of homocysteine in neurology: From labs to clinical practice. Int J Mol Sci. 2019; 20: 231

Nacci C, Tarquinio M, De Benedictis L, Mauro A, Zigrino A, Carratù MR, Quon MJ, Montagnani M. Endothelial dysfunction in mice with streptozotocin-induced type 1 diabetes is opposed by compensatory overexpression of cyclooxygenase-2 in the vasculature. Endocrinology 2009; 150: 849-61.

Niaz K, Zaplatic E, Spoor J. Extensive use of monosodium glutamate: A threat to public health? EXCLI J. 2018; 17: 273 78.

Niazi ZR, Najmanová I, Kamagaté M, Said A, Chabert $\mathrm{P}$, Auger C, Die-Kakou H, Schini-Kerth V. Preventive beneficial effect of an aqueous extract of Phyllanthus amarus Schum. and Thonn. (Euphorbiaceae) on DOCA-saltinduced hypertension, cardiac hypertrophy and dysfunction, and endothelial dysfunction in rats. J Cardiovasc Pharmacol. 2020; 75: 573-83.

Nie Q, Zhu L, Zhang L, Leng B, Wang H. Astragaloside IV protects against hyperglycemia-induced vascular endothelial dysfunction by inhibiting oxidative stress and calpain-1 activation. Life Sci. 2019; 232: 116662.

Oelze M, Knorr M, Schuhmacher S, Heeren T, Otto C, Schulz E, Reifenberg K, Wenzel P, Münzel T, Daiber A. Vascular dysfunction in streptozotocin-induced experimental diabetes strictly depends on insulin deficiency. J Vasc Res. 2011; 48: 275-84.
Olatunji LA, Seok YM, Igunnu A, Kang SH, Kim IK. Combined oral contraceptive-induced hypertension is accompanied by endothelial dysfunction and upregulated intrarenal angiotensin II type 1 receptor gene expression. Naunyn Schmiedebergs Arch Pharmacol. 2016; 389: 114757.

Olukman M, Can C, Erol A, Oktem G, Oral O, Cinar MG. Reversal of doxorubicin-induced vascular dysfunction by resveratrol in rat thoracic aorta: Is there a possible role of nitric oxide synthase inhibition? Anadolu Kardiyol Derg. 2009; 9: 260-66.

Oyabambi AO, Areola ED, Olatunji LA, Soladoye AO. Uric acid is a key player in salt-induced endothelial dysfunction: The therapeutic role of Stigma maydis (corn silk) extract. Appl Physiol Nutr Metab. 2020; 45: 67-71.

Pal PB, Sonowal H, Shukla K, Srivastava SK, Ramana KV. Aldose reductase regulates hyperglycemia-induced HUVEC death via SIRT1/AMPK-a1/mTOR pathway. J Mol Endocrinol. 2019; 63: 11-25.

Pieper GM, Langenstroer P, Siebeneich W. Diabetic-induced endothelial dysfunction in rat aorta: Role of hydroxyl radicals. Cardiovasc Res. 1997; 34: 145-56.

Qimuge A, Liu S, Wang H, Hu M, Song L. MAPK/AP-1 pathway activation mediates AT1R up-regulation and vascular endothelial cells dysfunction under PM2.5 exposures. Ecotoxicol Environ Saf. 2019; 170: 188-94.

Qin W, Zhang L, Li Z, Xiao D, Zhang Y, Zhang H, Mokembo JN, Monayo SM, Jha NK, Kopylov P, Shchekochikhin D, Zhang Y. Endothelial to mesenchymal transition contributes to nicotine-induced atherosclerosis. Theranostics 2020; 10: $5276-89$

Radovits T, Arif R, Bömicke T, Korkmaz S, Barnucz E, Karck M, Merkely B, Szabó G. Vascular dysfunction induced by hypochlorite is improved by the selective phosphodiesterase-5-inhibitor vardenafil. Eur J Pharmacol. 2013; 710: 11019.

Rameshrad M, Imenshahidi M, Razavi BM, Iranshahi M, Hosseinzadeh H. Bisphenol A vascular toxicity: Protective effect of Vitis vinifera (grape) seed extract and resveratrol. Phytother Res. 2018; 32: 2396-407.

Ren H, Mu J, Ma J, Gong J, Li J, Wang J, Gao T, Zhu P, Zheng $\mathrm{S}$, Xie J, Yuan B. Selenium inhibits homocysteine-induced endothelial dysfunction and apoptosis via activation of AKT. Cell Physiol Biochem. 2016; 38: 871-82.

Reventun P, Sanchez-Esteban S, Cook A, Cuadrado I, Roza C, Moreno-Gomez-Toledano R, Muñoz C, Zaragoza C, Bosch RJ, Saura M. Bisphenol A induces coronary endothelial cell necroptosis by activating RIP3/CamKII dependent pathway. Sci Rep. 2020; 10: 4190.

Ross EJ, Linch DC. Cushing's syndrome--killing disease: Discriminatory value of signs and symptoms aiding early diagnosis. Lancet 1982; 2: 646-69.

Sahara M, Sata M, Morita T, Hirata Y, Nagai R. Nicorandil attenuates monocrotaline-induced vascular endothelial damage and pulmonary arterial hypertension. PLoS One. 2012; 7: e33367.

Said MA. Vitamin D attenuates endothelial dysfunction in 
streptozotocin induced diabetic rats by reducing oxidative stress. Arch Physiol Biochem. 2020; 1: 1-5.

Sandoo A, van Zanten JJ, Metsios GS, Carroll D, Kitas GD. The endothelium and its role in regulating vascular tone. Open Cardiovasc Med J. 2010; 4: 302-12.

Saura M, Marquez S, Reventun P, Olea-Herrero N, Arenas MI, Moreno-Gómez-Toledano R, Gómez-Parrizas M, Muñóz-Moreno C, González-Santander M, Zaragoza C, Bosch RJ. Oral administration of bisphenol A induces high blood pressure through angiotensin II/CaMKII-dependent uncoupling of eNOS. FASEB J. 2014; 28: 4719-28.

Schafer SC, Wallerath T, Closs EI, Schmidt C, Schwarz PM, Forstermann U, Lehr HA. Dexamethasone suppresses eNOS and CAT-1 and induces oxidative stress in mouse resistance arterioles. Am J Physiol Heart Circ Physiol. 2005; 288: H436-44.

Schenk J, McNeill JH. The pathogenesis of DOCA-salt hypertension. J Pharmacol Toxicol Methods. 1992; 27: 161-70.

Shawky NM, Shehatou GS, Abdel Rahim M, Suddek GM, Gameil NM. Levocetirizine ameliorates high fructose dietinduced insulin resistance, vascular dysfunction and hepatic steatosis in rats. Eur J Pharmacol. 2014; 740: 353-63.

Si LY, Kamisah Y, Ramalingam A, Lim YC, Budin SB, Zainalabidin S. Roselle supplementation prevents nicotineinduced vascular endothelial dysfunction and remodelling in rats. Appl Physiol Nutr Metab. 2017; 42: 765-72.

Steven S, Oelze M, Brandt M, Ullmann E, Kröller-Schön S, Heeren T, Tran LP, Daub S, Dib M, Stalleicken D, Wenzel P, Münzel T, Daiber A. Pentaerythritol tetranitrate in vivo treatment improves oxidative stress and vascular dysfunction by suppression of endothelin-1 signaling in monocrotaline-induced pulmonary hypertension. Oxid Med Cell Longev. 2017; 2017: 4353462.

Taddei S, Virdis A, Ghiadoni L, Sudano I, Salvetti A. Endothelial dysfunction in hypertension. J Cardiovasc Pharm. 2001; 38: S11-14.

Taneja G, Mahadevan N, Balakumar P. Fish oil blunted nicotine-induced vascular endothelial abnormalities possibly via activation of PPARY-eNOS-NO signals. Cardiovasc Toxicol. 2013; 13: 110-22.

Tian R, Ding Y, Peng YY, Lu N. Myeloperoxidase amplified high glucose-induced endothelial dysfunction in vascularture: Role of NADPH oxidase and hypochlorous acid. Biochem Biophys Res Commun. 2017; 484: 572-78.

Ueno Y, Mohara O, Brosnihan KB, Ferrario CM. Characteristics of hormonal and neurogenie mechanisms of DOCinduced hypertension. Hypertension 1988; 11: 172-77.
Wang X, Chen L, Wang T, Jiang X, Zhang H, Li P, Lv B, Gao $X$. Ginsenoside Rg3 antagonizes adriamycin-induced cardiotoxicity by improving endothelial dysfunction from oxidative stress via up-regulating the Nrf2-ARE pathway through the activation of AKT. Phytomedicine 2015; 22: 875 -84 .

Wang XJ, Tian DC, Wang FW, Zhang MH, Fan CD, Chen W, Wang MH, Fu XY, Ma JK. Astaxanthin inhibits homocysteine induced endothelial cell dysfunction via the regulation of the reactive oxygen species-dependent VEGF VEGFR2 FAK signaling pathway. Mol Med Rep. 2019; 19: 4753-60.

Wassmann S, Bäumer AT, Strehlow K, Van Eickels M, Grohé C, Ahlbory K, Rösen R, Böhm M, Nickenig G. Endothelial dysfunction and oxidative stress during estrogen deficiency in spontaneously hypertensive rats. Circulation 2001; 103: 435-41.

Wu H, Wu J, Zhou S, Huang W, Li Y, Zhang H, Wang J, Jia Y. SRT2104 attenuates diabetes-induced aortic endothelial dysfunction via inhibition of P53. J Endocrinol. 2018; 237: 114

Yang S, Zhang L. Glucocorticoids and vascular reactivity. Curr Vasc Pharmacol. 2004; 2: 1-12.

Yang XY, Qiang GF, Zhang L, Zhu XM, Wang SB, Sun L, Yang HG, Du GH. Salvianolic acid A protects against vascular endothelial dysfunction in high-fat diet fed and streptozotocin-induced diabetic rats. J Asian Nat Prod Res. 2011; 13: 884-94.

Yin Y, Qi F, Song Z, Zhang B, Teng J. Ferulic acid combined with astragaloside IV protects against vascular endothelial dysfunction in diabetic rats. Biosci Trends. 2014; 8: 217-26.

Zhai X, Ren D, Luo Y, Hu Y, Yang X. Chemical characteristics of an Ilex Kuding tea polysaccharide and its protective effects against high fructose-induced liver injury and vascular endothelial dysfunction in mice. Food Funct. 2017; 8: 2536-47.

Zhang Y, Chen Y, Zhang Y, Li PL, Li X. Contribution of cathepsin B-dependent Nlrp3 inflammasome activation to nicotine-induced endothelial barrier dysfunction. Eur J Pharmacol. 2019; 865: 172795.

Zhao YX, Tong L, Zhang GM, Zhao XH, Sa YP, Liu Y, Lu DX, $\mathrm{Ga} \mathrm{Q}, \mathrm{Wu}$ P. L-Arginine supplementation improves vascular endothelial dysfunction induced by high-fat diet in rats exposed to hypoxia. Wilderness Environ Med. 2020; 31: $400-06$

Zhu J, Wang CG, Xu YG. Lycopene attenuates endothelial dysfunction in streptozotocin-induced diabetic rats by reducing oxidative stress. Pharm Biol. 2011; 49: 1144-49. 